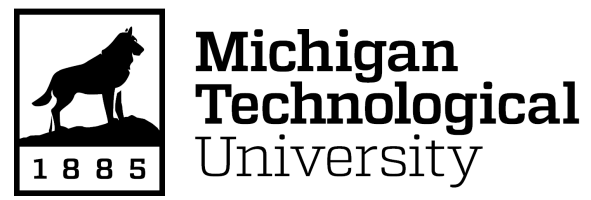

Michigan Technological University Digital Commons @ Michigan Tech

PREDICITNG FAILURE OF CULVERTS AND ASSOCIATED IMPACTS IN LOW ORDER STREAMS OF NORTHERN MICHIGAN

Charles King

Michigan Technological University, chking@mtu.edu

Copyright 2017 Charles King

Recommended Citation

King, Charles, "PREDICITNG FAILURE OF CULVERTS AND ASSOCIATED IMPACTS IN LOW ORDER

STREAMS OF NORTHERN MICHIGAN", Open Access Master's Thesis, Michigan Technological University, 2017.

https://doi.org/10.37099/mtu.dc.etdr/514

Follow this and additional works at: https://digitalcommons.mtu.edu/etdr 


\title{
PREDICITNG FAILURE OF CULVERTS AND ASSOCIATED IMPACTS IN LOW ORDER STREAMS OF NORTHERN MICHIGAN
}

By

C. Hunter King

\author{
A THESIS \\ Submitted in partial fulfillment of the requirements for the degree of \\ MASTER OF SCIENCE \\ In Forest Ecology and Management \\ MICHIGAN TECHNOLOGICAL UNIVERSITY \\ 2017
}

(C) 2017 C. Hunter King 
This thesis has been approved in partial fulfillment of the requirements for the Degree of MASTER OF SCIENCE in Forest Ecology and Management.

School of Forest Resources and Environmental Science

$\begin{array}{cc}\text { Thesis Co-Advisor: } & \text { Joseph W. Wagenbrenner } \\ \text { Thesis Co-Advisor: } & \text { Andrew J. Storer } \\ \text { Committee Member: } & \text { Casey J. Huckins } \\ \text { Committee Member: } & \text { David W. Watkins } \\ \text { Committee Member: } & \text { Mark A. Fedora } \\ \text { Committee Member: } & \text { Melanie K. Watkins }\end{array}$

School Dean: Terry L. Sharik 
Table of Contents

Preface 4

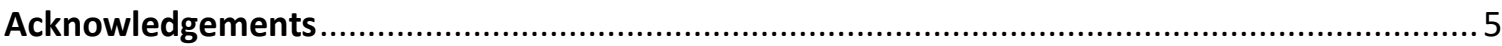

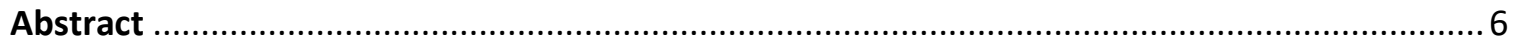

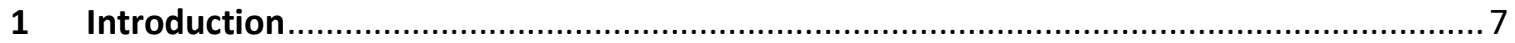

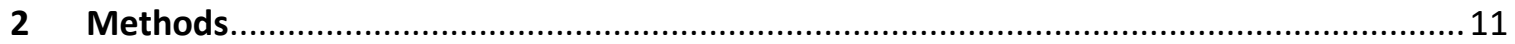

2.1 Research Area and Description.................................................................. 11

2.2 Coarse Resolution Inventories................................................................... 13

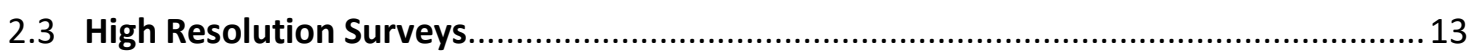

2.4 Estimating Flood Discharge Values for Culverts in the North Branch ....................... 16

2.5 Hydraulic Modeling of Culverts ................................................................... 18

2.6 Predicting Failure at a Culvert................................................................... 18

2.7 Economic Implications of Culvert Failure .................................................... 19

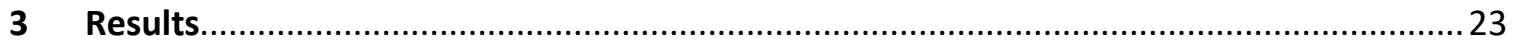

3.1 Coarse Resolution Inventory...................................................................... 23

3.2 Flood Discharge at Culverts in the North Branch ........................................... 25

3.3 Predictors of Culvert Failure ..................................................................... 28

3.4 Economic Implications of a Culvert Replacement in the North Branch .......................34

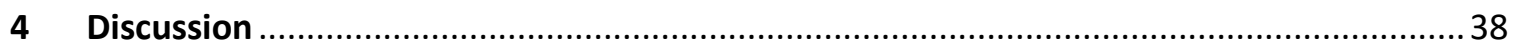

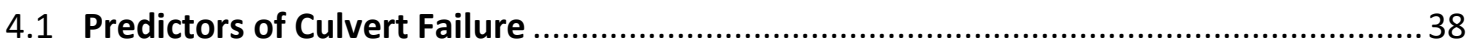

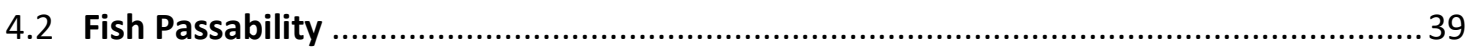

4.3 Effects of Climate on Culvert Failure ................................................................ 411

4.4 Age of Infrastructure and Culvert Failure....................................................... 422

4.5 Economic Impact of Single and Multiple Failures ............................................ 433

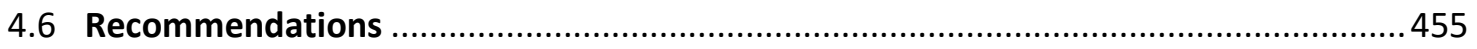

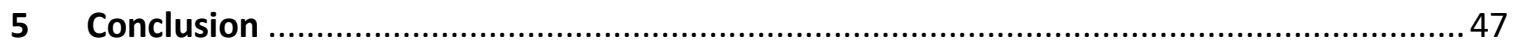

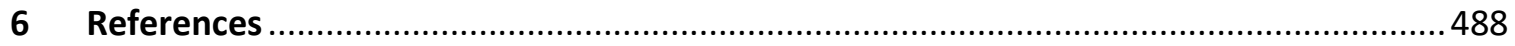

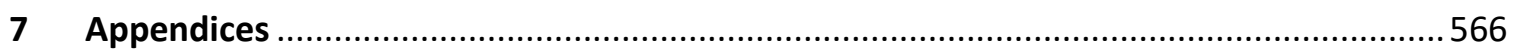

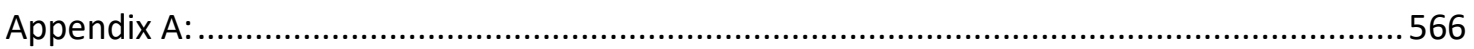

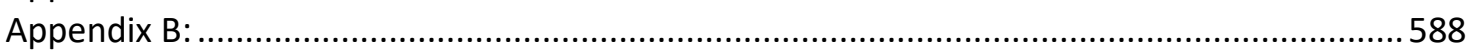

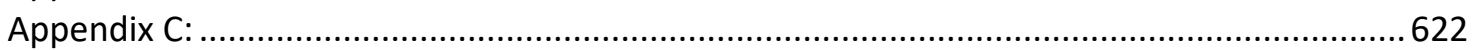

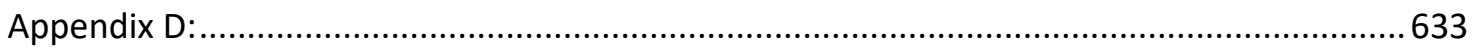

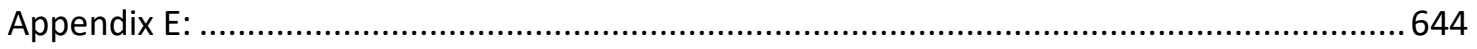

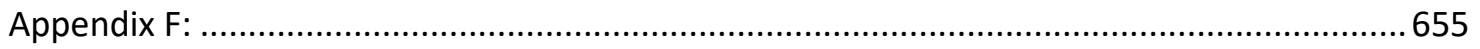

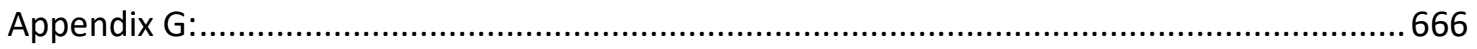

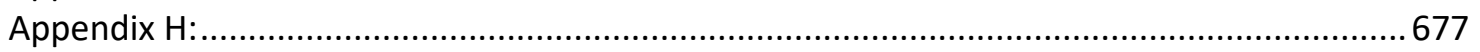




\section{Preface}

This thesis, and the studies within were composed in collaboration with hydrologists, civil engineers, and ecologists at Michigan Technological University and the USDA Forest Service. Joe Wagenbrenner of the USDA Forest Service contributed to the design and analytics of this research project, along with the editing of this thesis. Joe Wagenbrenner, Casey Huckins, David Watkins, Mark Fedora, and collaborators from the University of Wisconsin and The Nature Conservancy conceived the project and obtained funding. The scope of this collaborative project was to refine estimates to add to FishWerks (greatlakesconnectivity.org), a Great Lakes Basin wide stream connectivity optimization tool. 


\section{Acknowledgements}

The Great Lakes Fishery Trust, via a grant managed by the University of Wisconsin, and the USDA Forest Service provided funding for this research. Collaboration between the University of Wisconsin, Madison, USDA Forest Service and Michigan Technological University was essential to completing this thesis.

Thank you to my committee for their support, patience, and guidance through the duration of this project. Thank you to my advisor Dr. Joseph Wagenbrenner for all the revisions, instruction, intelligence, and expertise in the many fields within this research project. Thank you to Dr.

Melanie Kueber-Watkins for her experienced guidance through the hydraulic modeling process in this study. Thank you to Dr. Casey Huckins and Dr. David Watkins for their assistance and recommendations in survey setup, data analytics, revisions and support during this research project. Thanks to our Forest Service collaborator, Mark Fedora, for his help in the study design, real-world experience, and direction in this project.

This research would not have taken place without help in the field, and in the lab compiling data. Many thanks to Sarah Harttung, Brian Danhoff, and Margaret Kloote for assisting with inventories and surveys.

Thank you to my friends and family, especially my parents, for their support throughout my entire educational career. 


\section{Abstract}

The Great Lakes Region of North America has experienced more frequent extreme precipitation events recently, resulting in a large number of stream crossing failures. To evaluate failure risk and potential impacts of crossings in northern Michigan, we identified and conducted coarse assessments of all the stream crossings and dams in the North Branch Paint River Watershed. A subset of 11 culverts were selected from 49 identified sites for hydraulic analysis to estimate crossing failure discharge conditions. Stream crossing dimensions and upstream attributes were used to create metrics that predict failure risk without the need for complex hydraulic modeling, and these metrics were applied at the watershed scale. Sediment discharge and the economic impact associated with a failure event were also estimated for each stream crossing. Aquatic organism passability ratings were also determined for each crossing in the watershed. Five of the 11 modeled culverts were predicted to fail at discharges below the 50year flood. Upstream main channel length, bankfull width, culvert width, and upstream watershed area formed the best metrics for predicting failure with a combined $R^{2}$ value of 0.9 . Estimated cost of replacement was $19 \%$ more for a failed culvert than a planned replacement. Other unsurveyed culverts were analyzed to predicted failure condition discharge, and this resulted in an estimated cost of $\$ 1.4$ million in total culvert replacement throughout the watershed for the 11 total culverts that would likely fail during a 50 -year flood. Fish passability scores were lowest at culverts, and relationships between scores and risk of failure were assessed. Nine of the 20 culverts were impassable for fish year round, while $45 \%$ were barriers only at high flows. Risk of failure, in conjunction with organism passability, should be considered when prioritizing culverts for replacement. 


\section{Introduction}

Most of the transportation infrastructure in service today is the result of the economic booms that took place in the USA in the 1950s and 1960s; thus many of the stream crossings are approaching the end of their design life, prompting the design of techniques to assess their risk of failure (Biswas et al., 2001; Mai et al., 2014). These infrastructures (dams, bridges, and culverts) can fragment fluvial systems, and act as potential barriers to morphologic and ecologic processes in rivers (Brandt, 2000; Nilsson et al., 2005). Potential barriers affect morphological processes such as nutrient and sediment transport (Williams and Wolman, 1984; Collier et al., 1998; Wood and Armitage, 1997; Liriano and Day, 2001; Stanley and Doyle, 2003; McNeely et al., 2007). Potential barriers also affect organism dispersal (Pépino et al., 2012). Fragmentation of river connectivity influences organism population dynamics in terms of migration for reproduction, forage, refuge, and other life history traits (Warren and Pardew, 1998; Roni et al., 2002; Bowler and Benton, 2005; Nagrodski et al., 2012). Incorporating risk of failure techniques, along with stream connectivity impacts, in prioritization schemes to assess needed action at a potential barrier will optimize budgets, while restoring aquatic organism passage (AOP).

Prioritization of stream habitat restoration is a general term used for the step-by-step process of methods used by water resources managers, ecologists, and engineers to make decisions about the addition, alteration, or removal of potential barriers and other changes to improve the structure of riverine systems (McKay et al., 2016). The purpose of barrier removal or replacement projects is mainly to increase stream connectivity, or passability, for aquatic organisms. Prioritization provides a mechanism to optimize restoration under some constraint, usually financing. Common prioritization techniques include scoring, ranking, optimization or scenario analysis (Schick and Lindley, 2007; Hicks and Sullivan, 2008; Mount et al., 2011; King and O’Hanley, 2014; McKay et al., 2016). Progress in planning and prioritization process 
development has increased as barrier information becomes more widely available at larger spatial scales, allowing tools such as FishWerks (Moody et al., 2017, greatlakesconnectivity.org) to maximize the efficiency of connectivity improvement projects at the Great Lakes Basin scale.

As of 2013, Januchowski-Hartely et al. (2013) identified 276,027 potential aquatic organism barriers in the Great Lakes Basin, $97 \%$ of which were stream crossings. Within this population of stream crossings were bridges, which generally do not hinder aquatic organism passage and have relatively low likelihood of failure. The predominant type of stream crossings were culverts, which can significantly influence passability. Culverts cost less to install than bridges, resulting in their more widespread use (Gibson, 2005). Approximately $34 \%$ of stream crossings in the Great Lakes Watershed are impassable while $29 \%$ are partially passable, implying that around 170,000 crossings may impact connectivity for fish (Januchowski-Hartely et al., 2013).

An extensive amount of literature has proposed methods to prioritize barrier repair or removal to improve the opportunity for fish passage. McKay et al. (2016) reviewed 46 studies that examined barrier prioritization, and identify three steps in the prioritization process: establish the geographic extent of analysis, select a focal taxon, and identify management actions. The basis of these analyses is organism passage, and minimal consideration is given to prioritize a culvert based on its ability to convey potential flood flows and associated sediment or debris.

In the last two decades, the northern Great Lakes Basin has experienced several major flood events. In Marquette County, Michigan on May 13, 2003, substantial rains caused two dams to fail, one of which released over eight billion gallons of water creating damage to three other dams, and damage or destruction of nine bridges (Nault and Hayes, 2003). On June 20, 2012, 10.1 inches of rain fell in Duluth, Minnesota, greatly exceeding the area's 100-year 24- 
hour storm depth of 6.9 inches (Graning and Hluchan, 2012). Damage to public infrastructure was estimated to cost upwards of $\$ 80$ million (Cadotte, 2012), and the Federal Emergency Management Agency (FEMA) approved over $\$ 43.5$ million in public assistance for the disaster (FEMA, 2012). Another major flood occurred in October 2012 in the Canadian city of Wawa, Ontario. Every road in and out of town became impassable, stranding the 3,000 residents. Highway 101 , the only road leading to a community of 700 , was washed out at a stream crossing preventing access to food, medicine and other human necessities (Kelly, 2012). Unpublished data from a flood that occurred in Northern Wisconsin on July 11, 2016 estimated flows at culvert failure sites that were 7.5 times greater than the 500 -yr flow estimates (Dale Higgins, USDA Forest Service, 2017 unpublished data). Estimated damage to public infrastructure cost \$26 million (Kaeding, 2017).

Culvert failure conditions are complex and variable in nature. The two main failure conditions are inadequate flow capacity and structural collapse (Lian and Yen, 2003). The Great Lakes Basin is at risk of substantial increase in 'great' flood events according to climate change simulations composed by Milly et al. (2002). Thus, failure at culverts may become more common due to inadequate and outdated design. Structural collapse may also occur when the structure cannot handle a freight load (i.e. crushed), or prolonged erosional process at the culvert (Lian and Yen, 2003).

Research has been integrated in culvert design to account for varied estimated flood discharges (Hager et al., 1998; FHWA 2012; Cafferata et al., 2004). Less effort has been put forth towards inventorying and prioritizing stream crossings that have a higher potential of failing under estimated flood values. Fitzgerald and Clifton (1998) inventoried 86 stream crossings in a watershed of southeast Washington and northeast Oregon after flooding in winter 1995-1996. Their analysis found that $51 \%$ of the crossings failed, and that sediment and wood restricted 
flow at the majority of these failed crossings. Examination of failed culverts in the Pacific Northwest by Cafferata et al. (2004) concluded that large woody debris and sediment caused reduction in flow capacity, and this was the most common mechanism of culvert failure. They recommend the headwater depth to culvert diameter ratio (HW/D) be no larger than 1 in lower sloped watersheds, while no larger than 0.67 in mountainous watersheds with high slopes to accommodate wood and sediment passage associated with flood flows. Piehl et al. (1988) also argue that failure at a culvert has potential to occur when HW/D>1.

Given the increase of large storm events in the Great Lakes Basin, assessing the risk of culvert failure should be included in regional prioritization techniques. However, tools to predict flows and hydraulic conditions at culverts are complex and data intensive, and there is a need to develop simple assessment procedures from readily available data. This study assessed the vulnerability of culverts in the North Branch Paint River, Iron County, Michigan, USA (Figure 2.1), to failure at high flows by determining the maximum capacity that the culverts can withstand before failure. Peak discharge estimates over a range of return periods were established under current climatic conditions. Predictors of culvert failure were assessed through testing ratios created from GIS-derived measurements and coarse level survey data. Multiple linear regression was used to predict the failure condition at every non-surveyed culvert in the watershed. We also assessed the habitat connectivity impacts of potential barriers for resident fish passability using established criteria. Finally, cost estimates for planned culvert replacements and replacements after failure were estimated and compared. 


\section{$2 \quad$ Methods}

Stream crossings in the North Branch Paint River watershed were identified, surveyed, and analyzed. A subset of crossings was used for in-depth analysis, and the results from this sample were extended to the watershed scale.

\subsection{Research Area and Description}

The research area consisted of the North Branch Paint River (North Branch) watershed located in the Ottawa National Forest of Michigan's Upper Peninsula (Figure 2.1). As of 2011, landuse in the $116.9 \mathrm{mi}^{2}$ North Branch was $66.9 \%$ forested, $30.7 \%$ open water or wetland, and 2.4\% developed (Homer, 2015). Of the forests, $41.4 \%$ were coniferous, $40.9 \%$ were deciduous, and $17.6 \%$ were a mixture of both (Homer, 2015). Glacial deposits dominated by sand (68\%) and silt (28\%) were composed of soil classes of spodosols (68.9\%), inceptisols (27.7\%), and histolsols $(16.7 \%)$ in the watershed (Soil Survey Staff, 2017). The North Branch had an average saturated permeability rate of $7.3 \mathrm{inhr}^{-1}$ and a mean slope of 2.7\% (Soil Survey Staff, 2017; NRCS, 2017). Average monthly precipitation in Amasa, MI, 14 miles east of the North Branch watershed boundary, was 2.3 inches per month from 1997-2017 (NCEI, 2017). Spring snowmelt is a dominant hydrologic influence in the Upper Peninsula, and an average of 212 in $\mathrm{yr}^{-1}$ of snow fell in Kenton, MI, 7 miles north of the North Branch watershed Boundary, from 2005-2016 (Damon Haan, USDA Forest Service, 2017, unpublished data). The North Branch stream orders range from 1 to 4 (Strahler, 1957), and the Paint River is a tributary to the Menominee River and Lake Michigan.

An assessment using satellite and near surface remote imagery analysis determined the North Branch to have a road density of 5.2 miles of road per square mile, with a total of 605 miles of road in the watershed (Banach et al., 2016). These data identified 58 potential fish 
passage barriers in the North Branch, including dams, culverts, bridges, fords, footbridges, and removed crossings (Banach et al., 2016). This number was greater than the number of crossings detected by the intersection of the total flow line with the State of Michigan's "All Roads" shapefile, which suggested 27 stream crossings (State of Michigan, 2014). The Banach et al. (2016) data also had more crossings than data previously used by the Forest Service, which indicated that roads intersected the North Branch at 36 points (Amy Amman, USDA Forest Service, personal communication, 14 Nov 2017). The differences among the data sets are due to the inclusion of all roads and trails in the remotely sensed data set assembled by Banach et al. (2016), including decommissioned routes, as well as dams. Extensive ground reconnaissance via hiking and paddling in summer 2016 identified 49 potential barriers.

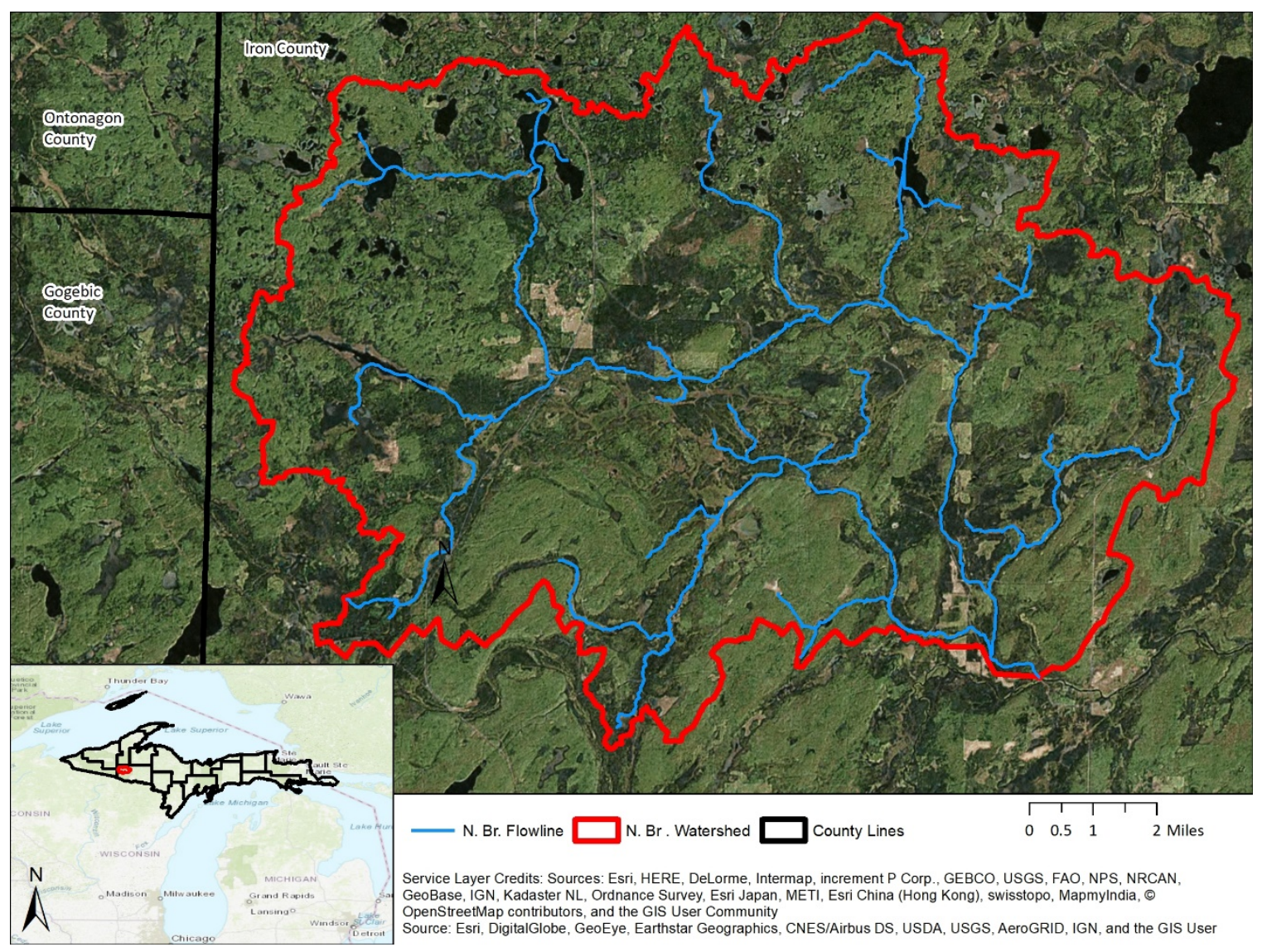

Figure 2.1: Location of the North Branch Paint River Watershed in Iron County and the Upper Peninsula of Michigan. 


\subsection{Coarse Resolution Inventories}

The 49 crossings and dams were inventoried in May and June 2016 following the Great Lakes Road Crossing Inventory Instructions (GLRCII) (GLRSCII, 2011) (Appendix A). Qualitative observations included crossing type, construction material, and condition of the crossing. Measurements included road width, structure height, structure length, structure width, stream bankfull width, wetted width, and average wetted depth. Road characteristics such as approach length, slope, and adjacent low point were measured, and road fill depth above the culvert was estimated. Thalweg stream velocities were measured at the inlet and outlet of each structure, and in the stream where the channel was not apparently impacted by the crossing, with a handheld acoustic doppler velocimeter (SonTek, San Diego, CA, USA).

Fish passability ratings at each potential barrier (Diebel et al., 2009), were determined based on water depths and velocities and outlet perch height. Scores were assigned as follows: 0 indicated that most fish at all life stages would not be able to pass the structure; 0.5 indicated some species at different life stages would be able to pass; 0.9 suggested the structure was a barrier only at high flows; and 1 indicated the structure was not a barrier (Diebel et al., 2009). Velocities and passability ratings were for observed flow conditions, which varied from approximately half bankfull to bankfull.

\subsection{High Resolution Surveys}

Eleven culverts were chosen for high-resolution surveys and hydraulic modeling to predict flow conditions at failure. Five of the nine culverts with passability ratings of 0 were randomly selected (Figure 2.2). Six surveyed culverts were randomly selected from the remaining 11 culverts with passability scores greater than 0 (Figure 2.2). At each culvert, the coordinates of the road prism, culvert inlet, culvert outlet, and flood plain and stream channel 
along four cross-sections were surveyed with a total station. A total station is an electronic distance measurement instrument that determines the spatial coordinates of the position identified using a reflecting prism by reflectance and angle measurements. From multiple point measurements, elevation surfaces, and distances and slopes between points can be derived.

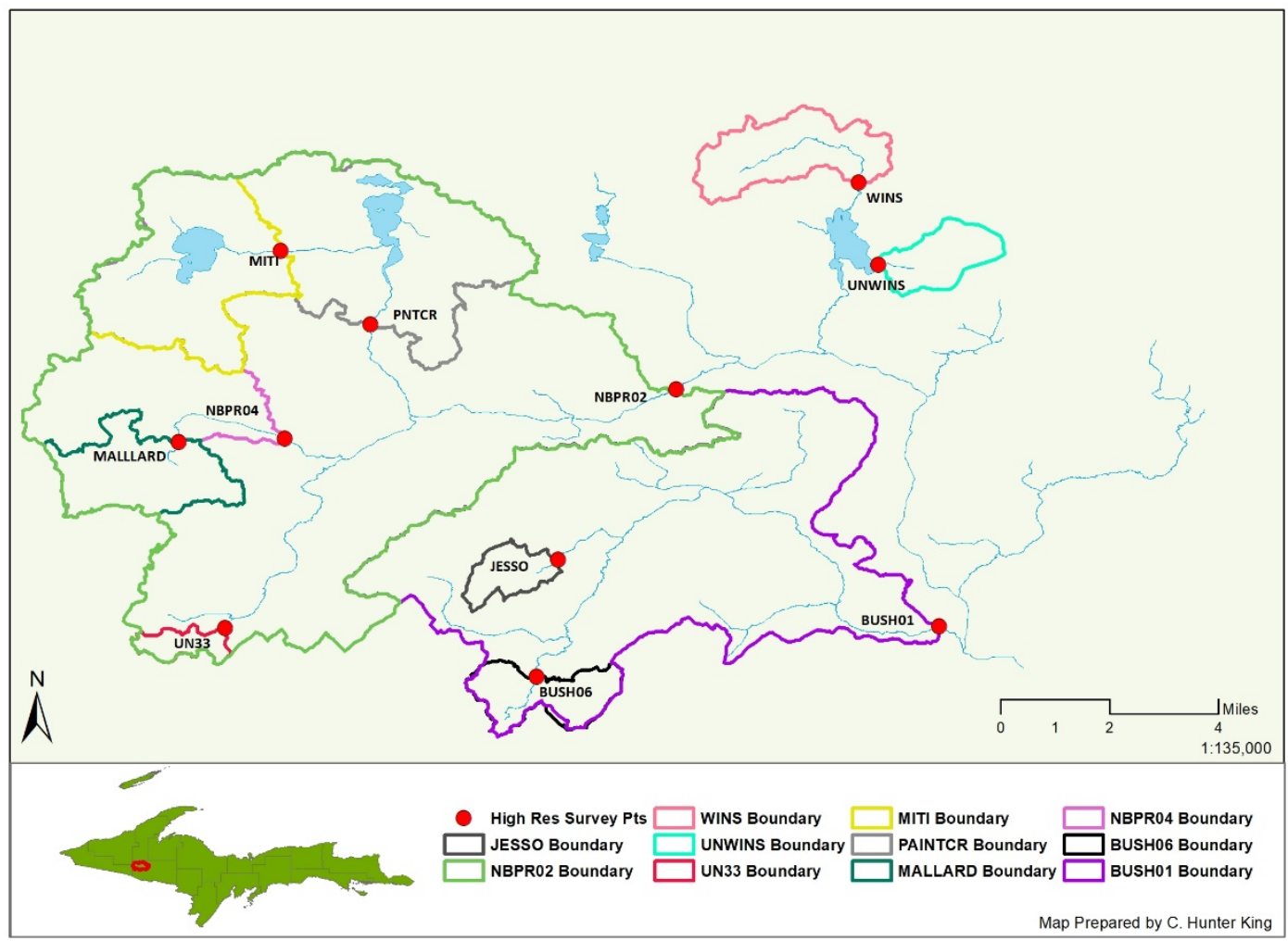

Figure 2.2: Location, site identifier, and subwatershed of each high resolution survey site in the North Branch.

We surveyed two cross sections upstream, and two cross sections downstream of each culvert, and extended each cross section into the floodplain. The cross sections located farthest from the culvert were selected so that channel and floodplain were not apparently impacted by the culvert. The other two cross sections were located within $10 \mathrm{~m}$ of the inlet or outlet to represent flow contraction and expansion conditions at the culvert. Thalweg channel elevations 
were surveyed beyond the farthest upstream and downstream transects to establish channel slopes near the culvert.

Elevation points on the road prism, the trapezoidal cross-sectional shape composed of the road tread and fill which crosses the floodplain, were also surveyed. Road prism points were measured at the top of the road, approximately half way down each fill slope, and at the point where the road fills met the floodplain (Figure 2.3). These measurements were made at approximately equidistant intervals along the road averaging between 15 and $40 \mathrm{ft}$ spanning the floodplain width (e.g. Figure 2.3). Total station surveys averaged 203 points per site and ranged from 146 to 267 points per site. High resolution surveys were done in August 2016 and May 2017.

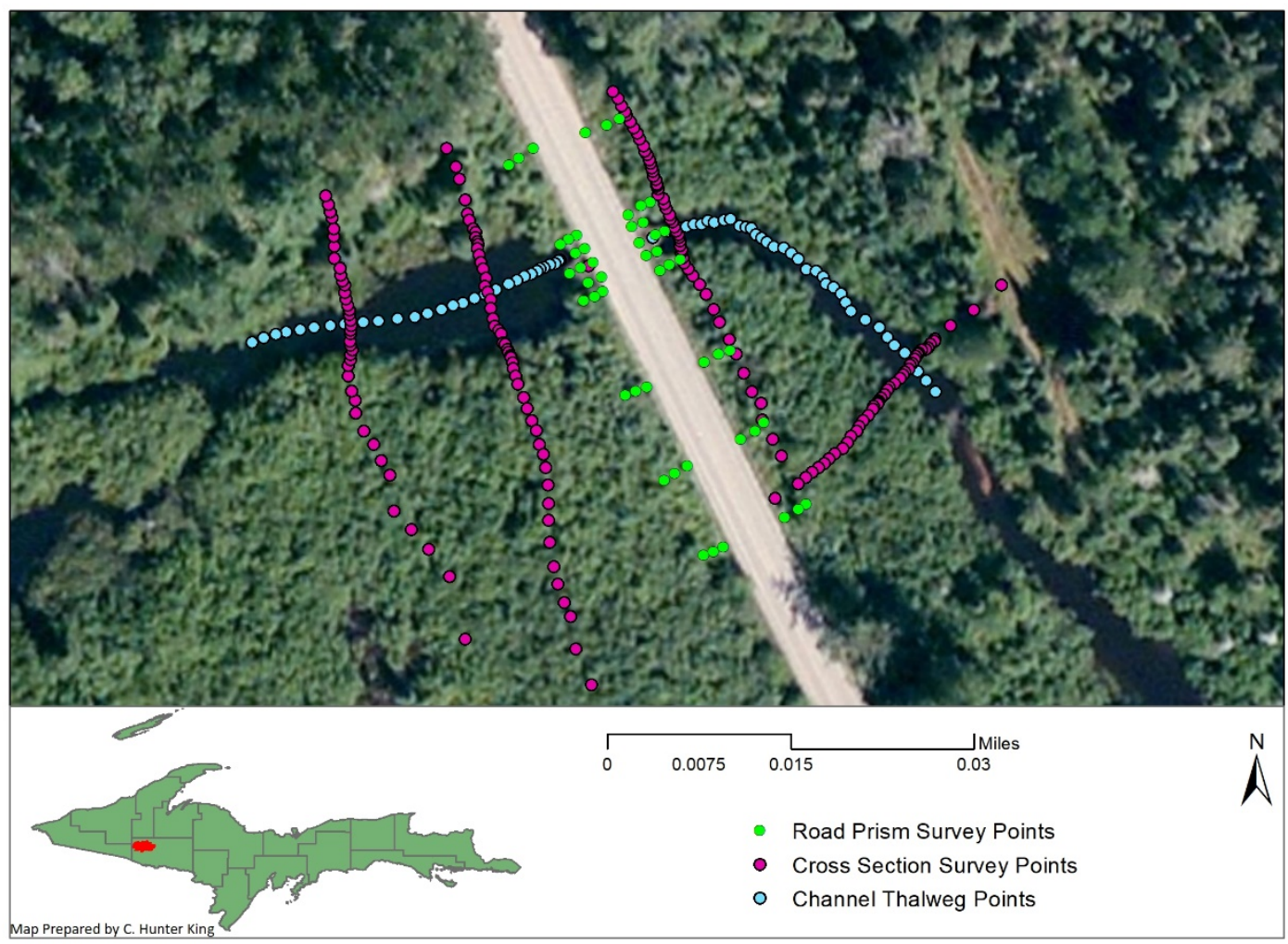

Figure 2.3: Cross section, road prism, and thalweg survey points at BUSH01. 


\subsection{Estimating Flood Discharge Values for Culverts in the North Branch}

There is no streamflow gage in the North Branch watershed, thus gaged reference reaches were used to select a method for estimating stream flows. Gages on the Black River, Middle Branch Ontonagon River, and the Iron River are located 13-68 miles from the outlet of the North Branch (Table 2.1). Log Pearson Type III (LP3) probability analysis of annual peak discharge values was used to determine return periods of the observed flows at the gaged sites (USGS, 1982).

Table 2.1: River Name, USGS gage number, distance from the North Branch, upstream watershed area, and length of record for each reference gage used to establish flood discharge values for the ungaged North Branch (USGS A; B; C, 2016).

\begin{tabular}{lcccc}
\hline River Name & $\begin{array}{c}\text { USGS } \\
\text { Gage } \\
\text { Number }\end{array}$ & $\begin{array}{c}\text { Distance } \\
\text { from N. Br. } \\
\text { Outlet } \\
(\mathrm{mi})\end{array}$ & $\begin{array}{c}\text { Watershed Area } \\
\left(\mathrm{mi}^{2}\right)\end{array}$ & $\begin{array}{c}\text { Length of } \\
\text { Record } \\
\text { (years) }\end{array}$ \\
\hline Black River & 4031000 & 68 & 200 & 45 \\
Iron River & 4060500 & 13 & 92 & 45 \\
Mid. Br. Ontonagon River & 4033000 & 19 & 164 & 70 \\
\hline
\end{tabular}

Values from four peak discharge models were calculated from watershed attributes (Table 2.2) for each reference stream. The four models were: USGS Wisconsin Zone 4 regression equation (Walker and Krug, 2003); USGS Michigan Zone 1 regression equation (Holtschlag and Crosky, 1984) using the 1961 (USDC, 1961) and 2013 (NOAA, 2013) estimates of 100-yr, 24-hr precipitation; and the Michigan Department of Environmental Quality's (MDEQ) method for computing flood discharges for small ungaged watersheds (Sorrell, 2010) (Table 2.2).

Input values for the four models were derived from GIS (ESRI, 2017). Contributing area was derived from a 10-meter digital elevation model (DEM) (NRCS, 2017) using hydrology tools in ArcGIS (ESRI, 2017). Main channel slope was computed as the difference in elevation between points at $10 \%$ and $85 \%$ of the watershed's hydraulic length above the culvert, where $100 \%$ is the watershed boundary, divided by the stream distance between points. The hydraulic length is the 
linear distance of the longest flow path in a watershed. River channel length adjacent to wetland and open water was determined as the length of intersect of the watershed's main flow line and the National Wetlands Inventory's designated wetlands layer (Cowardin et al., 1979).

Slenderness ratio was determined by squaring the hydraulic length (mi) and dividing by the contributing area $\left(\mathrm{mi}^{2}\right)$. Soil characteristics were clipped to the watershed boundary from the State of Michigan's Quaternary Geology layer, and the percent of each soil type within the watershed was identified (Farrand and Bell, 1982).

Table 2.2: Flood discharge methods, models inputs, and sources of models used for comparison to gaged values in reference streams.

\begin{tabular}{|c|c|c|}
\hline Method & Geomorphic and Climate Inputs & Source \\
\hline $\begin{array}{l}\text { Wisconsin } \\
\text { Zone } 4 \\
\text { Regression } \\
\text { Equation }\end{array}$ & $\begin{array}{l}\text { Contributing watershed area }\left(\mathrm{mi}^{2}\right) \\
\text { Water storage in watershed (\%) } \\
\left.\text { Main channel slope }(\mathrm{ft} \mathrm{mi})^{-1}\right) \\
\text { Soil permeability in watershed (in } \mathrm{hr}^{-1} \text { ) } \\
\text { Average annual snowfall (in) }\end{array}$ & $\begin{array}{l}\text { Walker } \\
\text { and Krug, } \\
2003\end{array}$ \\
\hline $\begin{array}{l}\text { Michigan } \\
\text { Zone } 1 \\
\text { Regression } \\
\text { Equation }\end{array}$ & $\begin{array}{c}\text { Contributing watershed area }\left(\mathrm{mi}^{2}\right) \\
\text { Hydraulic length }(\mathrm{ft}) \\
\text { Main channel slope }\left(\mathrm{ft} \mathrm{mi}^{-1}\right) \\
\text { Length of stream adjacent to lake or wetland (ft) } \\
\text { USDC, } 1961 \text { or NOAA, } 2013100 \mathrm{yr}-24 \mathrm{hr} \text { precipitation } \\
\left.\text { intensity (in } \mathrm{hr}^{-1}\right) \\
\text { Quaternary soil type } 2,3,5,7,8,10-13,15(\%)\end{array}$ & $\begin{array}{l}\text { Holtschlag } \\
\text { and Crosky, } \\
1984\end{array}$ \\
\hline MDEQ & $\begin{array}{c}\text { Contributing drainage area }\left(\mathrm{mi}^{2}\right) \\
\text { MI Zone } 1100 \mathrm{yr}-24 \mathrm{hr} \text { precipitation intensity }\left(5.32 \mathrm{in} \mathrm{hr}^{-1}\right) \\
\text { Time of concentration (hours) } \\
\text { Rainfall runoff curve number }\end{array}$ & Sorrell, 2010 \\
\hline
\end{tabular}

Estimated discharge values from each of the reference gage sites were compared with discharge estimates for the North Branch using linear regression. The USGS Michigan Zone 1 regression equation using the 2013 precipitation intensity best fit the LP3 peak discharge estimates across the three reference gages (Appendix B). This equation was used to predict the 
discharge at each culvert as an input to the hydraulic model (Section 2.5). Michigan Zone 1 regression equations and the associated inputs are shown in Appendix C.

\subsection{Hydraulic Modeling of Culverts}

We simulated a river reach from the cross section and longitudinal survey data in the Hydrologic Engineering Center-River Analysis System 5.0.3 (HEC-RAS) modeling software (U.S. Army Corps of Engineers, 2016). Manning's $n$ values for the right and left floodplain, the channel, and the culvert were derived from a reference table (Brunner, 2016). Subcritical flow contraction and expansion coefficients, weir coefficients, entrance and exit loss coefficients and other culvert data were obtained from the HEC-RAS guidelines (Brunner, 2016) for each modeled site.

Culvert information, including construction material, length, height, width, and headwall conditions, was obtained from the coarse surveys. Discharge (Q) values derived from the regression equations (Section 2.4) were used to predict flow depths at the culvert for the 2, 5, $10,25,50,100,200$, and 500-year return period flows. We assumed that failure would occur at a headwater depth to culvert diameter (HW/D) ratio of 1 and calculated the discharge at failure (Qtop) for each modeled culvert through iterative model runs. The return period for the failure discharge was derived from the best-fit equation between discharge and return interval for each modeled culvert.

\subsection{Predicting Failure at a Culvert}

A failure ratio was used to normalize failure flows across surveyed culverts. The ratio was the estimated Qtop divided by the 50-year discharge value (Q50) derived from the USGS regression equation (Section 2.4). Q50 was selected as it is a common discharge used for designing culverts (FWHA, 2012). Failure ratios greater than 1 indicated failure would occur at a 
discharge greater than Q50. Similarly, ratios less than 1 indicated failure would occur at a discharge less than Q50. Because the precise flood recurrence interval associated with culvert failure was indistinguishable at discharges greater than 500-year interval, use of this ratio also reduced the impact of individual Qtop values that exceeded 500-year return intervals.

Watershed attributes (Appendix E), culvert dimensions (Appendix F), and upstream bankfull conditions (Appendix G) were correlated with failure condition across sites. These measurements and attributes were used to create metrics that might predict the failure condition at other culverts without the step of hydraulic modeling. In total, 61 metrics (Appendix $\mathrm{H}$ ) were calculated and tested. Linear regression was used to examine relationships between each metric and the failure ratio using the correlate function in $R$ ( $R$ Core Team, 2013) in RStudio (RStudio Team, 2015). $\mathrm{R}^{2}$ values greater than 0.3 indicated significant correlation between the metrics and failure condition across surveyed sites.

Multiple linear regression was also used to assess the failure condition. A model was built through forward selection to predict failure at other culverts in the North Branch that were not surveyed at high resolution. The independent culvert measurement with highest correlation to failure condition was used (Appendix F). Similarly, the bankfull condition and watershed attribute with the highest $R^{2}$ value was used in the multiple linear analysis (Appendix $G$, Appendix E). Watershed area was also used in the linear analysis.

\subsection{Economic Implications of Culvert Failure}

We assessed the cost of a culvert failure by comparing the cost of a planned culvert replacement $\left(T_{P}\right)$, to the cost of a replacement after culvert failure $\left(T_{F}\right)$ at the same site. Adaptions to Perrin and Jhaveri's (2004) life cycle cost analysis for replacing culverts were used to estimate $T_{p}$ :

$$
T_{P}=C_{R}+C_{S P}+C_{D P} \ldots \ldots \ldots \text {.... Equation } 1
$$


where $C_{R}$ is the cost of replacement, $C_{S P}$ is the cost of service associated with a planned culvert replacement, and $C_{D P}$ is the cost of user delay associated with planned culvert replacement. The cost of culvert failure $\left(T_{F}\right)$ was estimated by

$$
T_{F}=C_{R}+C_{S F}+C_{D F}+C_{G F}+C_{E F} \ldots \ldots \ldots . . . \text { Equation } 2
$$

where $C_{R}$ is the cost of replacement, $C_{S F}$ is the cost of service associated with a failed culvert replacement, $C_{D F}$ is the cost of user delay associated with failed culvert replacement, $C_{G F}$ is the cost to replace lost road fill, and $\mathrm{C}_{\mathrm{EF}}$ is the cost to remove sediment mobilized into the channel after failure.

Data from Great Lakes Road Crossing Inventory surveys in northern Wisconsin were used to create a Microsoft Access (Microsoft Corp., 2017) tool to estimate $C_{R}$ (Diebel, 2009). Inputs from the coarse survey are: structure type, bankfull width, structure length, structure width, road width, road surface type, and fill depth above culvert. This tool was used to establish estimates of $C_{R}$ in 2009 dollars, and we applied an annual inflation rate of $1.7 \%$ to convert to 2017 dollars (BLS, 2017). Fixed costs in this tool are shown in Table 2.3:

Table 2.3: Fixed cost type and amount in $2009 \$$ used in estimating $C_{R}$

\begin{tabular}{ccccc}
\hline Type & $\begin{array}{c}\text { Excavation } \\
\left(\$ / \mathrm{yd}^{3}\right)\end{array}$ & $\begin{array}{c}\text { Backfill } \\
\left(\$ / \mathrm{yd}^{3}\right)\end{array}$ & $\begin{array}{c}\text { Bedding } \\
\left(\$ / y d^{3}\right)\end{array}$ & $\begin{array}{c}\text { Crown Fill } \\
\left(\$ / \mathrm{yd}^{3}\right)\end{array}$ \\
\hline Cost $(2009 \$)$ & 12 & 8 & 16 & 6 \\
\hline
\end{tabular}

Service cost $\left(C_{S}\right)$ is an estimate for the cost of oversight and engineering associated with replacing a culvert. We used a $C_{S}$ value of $20 \%$ of $C_{R}$ to estimate total planned cost $\left(T_{P}\right)$ (O'Shaughnessy et. al., 2016). Data for personnel costs during emergency replacement are not readily available, so we assumed $30 \%$ of $C_{R}$ to cover overtime cost and estimate the total failure $\operatorname{cost}\left(T_{F}\right)$.

The cost of loss of use, or user delay $\left(C_{D}\right)$ after a culvert failure, was estimated using the approach of Perrin and Jhaveri (2004): 


$$
C_{D}=T \times H \times D \times\left(C_{P} \times V_{P} \times V_{O}+C_{F} \times V_{F}\right) \ldots \ldots \ldots \text { Equation } 3
$$

where $\mathrm{T}$ is the annual average daily traffic, which is estimated at 10 cars for forest roads in the Ottawa National Forest. $\mathrm{H}$ is the amount of delay in hours, and we assumed one hour of delay time based on the approximate speed and distance needed to detour around any single failed crossing (Banach et al., 2016); and D is the number of days the road is unpassable. We assumed a D of 2 days for planned replacements based on personal experience with culvert replacements, and 10 days for a failed replacement (Mark Fedora, USDA Forest Service, personal communication, 31 Oct 2017). $C_{P}$ is the cost per person hour, which was estimated at \$24 per hour by inflating 2002 dollars at $2.1 \%$ to 2017 dollars (USDL, 2002; BLS, 2017). VP is the percent of passenger vehicle volume, which was estimated at $97 \%$ (TRB, 2000); and $V_{0}$ is the vehicle occupancy, which was estimated at 1.2 people per vehicle (Perrin and Jhaveri, 2004). $C_{F}$ is the cost per freight hour, estimated at $\$ 70$ per freight hour by inflating 2002 dollars at $2.1 \%$ to 2017 dollars (USDL, 2002; BLS, 2017), and $V_{F}$ is the percent of freight traffic volume, which was estimated at 3\% (TRB, 2000).

Failed culverts would contribute sediment from the road prism to the stream channel, and this material would need to be replaced to re-open the crossing and would also need to be removed from the stream to return it to its pre-failure condition. The cost of fill replacement $\left(\mathrm{C}_{\mathrm{G}}\right)$ was determined from estimating the total volume of fill that was mobilized from the road prism during failure. The lost volume was conservatively estimated by multiplying the road prism cross-sectional area times the downstream bankfull width, and subtracting the culvert volume (Figure 2.4). 


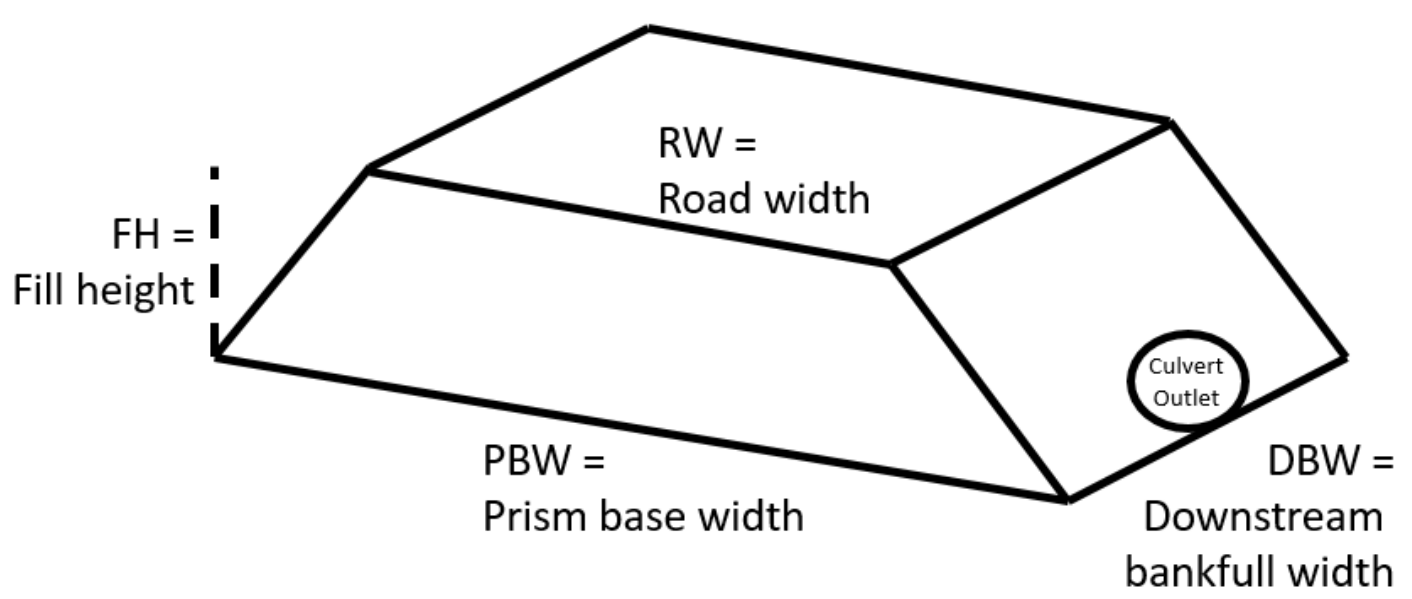

Figure 2.4: Road prism dimensions

This gives:

Lost volume $=\frac{R W+P B W}{2} \times F H \times D B W-$ culvert volume..........Equation 4

Culvert volume will vary with the shape of culvert, typically cylindrical or rectangular. Cost of sediment replacement $\left(C_{G}\right)$ assumes an average of $\$ 29 / \mathrm{yd}^{3}$ of lost sediment (Neeson et al., in review).

The estimated cost for sediment removal from the stream $\left(C_{E}\right)$ is $\$ 25 / y d^{3}$ of lost sediment plus $\$ 4160$ per day in operator and additional costs (Brian Halm, Streamside Environmental, personal communication, 27 Oct 2017). The dredge is able to remove 750 $\mathrm{yd}^{3} / \mathrm{day}$, and therefore would only be needed for one day for each site in the North Branch. Sediment removed from the stream would be deposited at a site located near the failed crossing, outside of the floodplain. The cost of removal of the sediment from the stream is one method to determine the economic value of the degradation of the ecosystem attributed to the culvert failure (Loomis et al., 2000). 


\section{$3 \quad$ Results}

\subsection{Coarse Resolution Inventory}

Ground surveys led to the confirmation of 49 potential barriers, which include 20 culverts, 19 bridges, 8 dams, and 2 fords, and exclude removed crossings (Figure 3.1). This is nine less that the MTRI analysis for barriers in the watershed (Banach et al., 2016). Seventy-five percent of inventoried culverts occurred on first-order streams in the North Branch. Details of each potential barrier, including the type, material, dimensions and fish passability score, can be found in Appendix D.

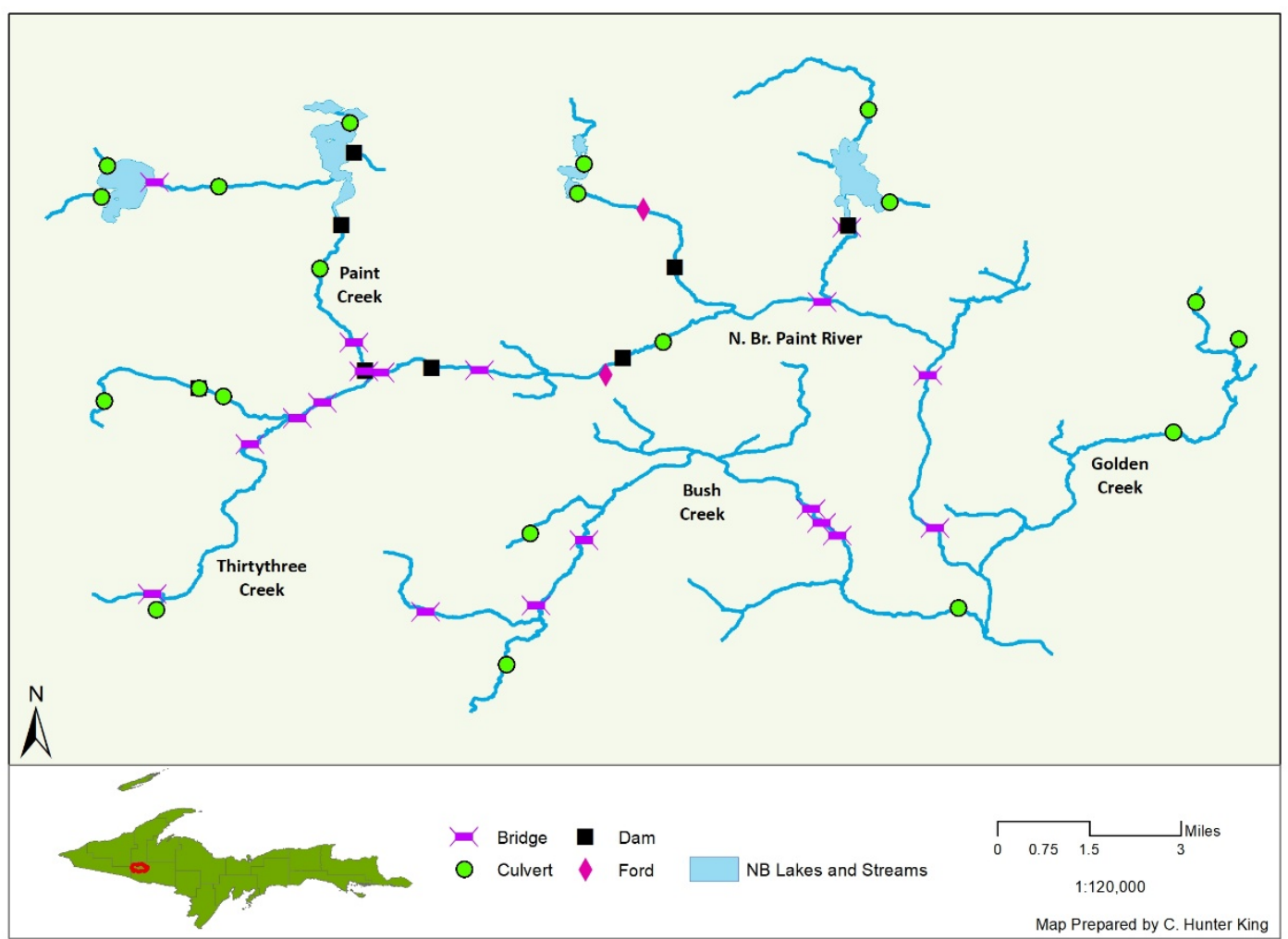

Figure 3.1: Inventoried potential barrier type and location in the North Branch (does not include removed crossings).

Fish passability scores were given to each potential barrier. Thirty-five percent of all potential barriers had a passability score of 1 , and $37 \%$ had a score of 0 (unpassable) (Figure 
3.2). The majority of the remaining $28 \%$ of the barriers had a score of 0.9 , indicating they would be barriers to passage only at high flow periods. Every dam in the watershed was unpassable. Every ford, $74 \%$ of the bridges, and $5 \%$ of the culverts had passability score of 1 , allowing fish at all life stages to mobilize upstream and downstream (Figure 3.2). Forty-seven percent of the culverts were unpassable all year for fish at every life stage. The single bridge with the passability score of 0 was a decrepit all-terrain vehicle bridge constructed of logs and planks without any structural support spanning the river, causing debris build-up and scour. Eight of the ten crossings (excluding dams) with passability ranking of 0 occurred on first-order streams.

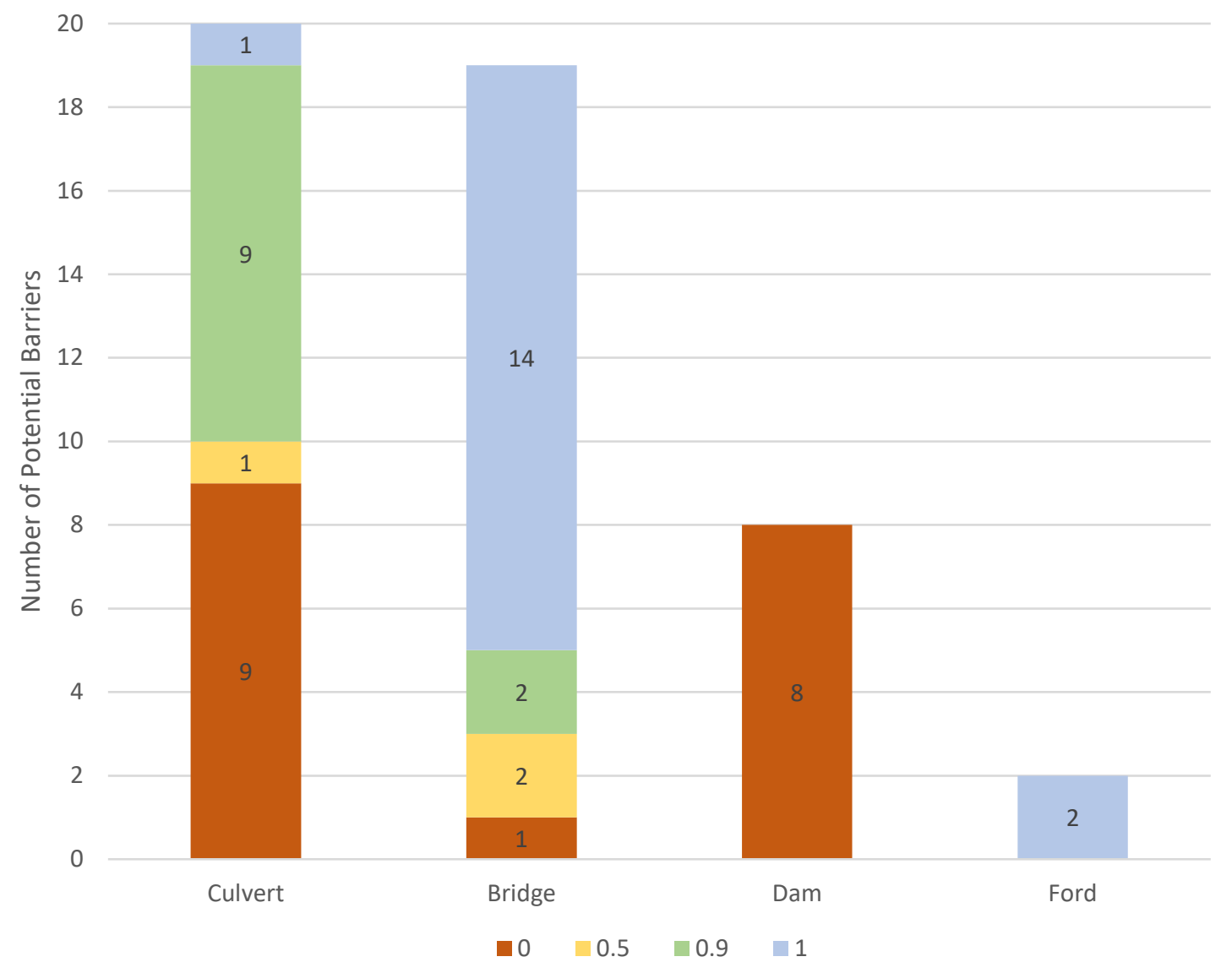

Figure 3.2: Number of potential barriers in each fish passability rating category by stream crossing type. 


\subsection{Flood Discharge at Culverts in the North Branch}

Subwatershed drainage area (DA) upstream of analyzed culverts ranged from $0.5 \mathrm{mi}^{2}$ at JESSO to $46.6 \mathrm{mi}^{2}$ at NBPRO2 (Table 3.1). The average main channel slope upstream of culverts was $0.38 \%$, with maximum slope above JESSO $(0.97 \%)$ and minimum slope occurring above NBPRO4 (0.08\%) (Table 3.1). Each location was assumed to have a 100-yr, 24-hr precipitation value of $5.81 \mathrm{in} \mathrm{hr}^{-1}$ (NOAA, 2013). Table 3.1 shows other inputs used in the USGS regression equation. Estimated discharge (Q) values for the 2, 5, 10, 25, 50, 100, 200, 500-year flood event at each of the 11 culverts surveyed are shown in Table 3.2. Q2 ranged from 6 to $21 \mathrm{ft}^{3} \mathrm{~s}^{-1} \mathrm{mi}^{-2}$, and Q500 ranged from 24 to $129 \mathrm{ft}^{3} \mathrm{~s}^{-1} \mathrm{mi}^{-2}$ across sites. Average Q50 at culverts in the North Branch was $43 \mathrm{ft}^{3} \mathrm{~s}^{-1} \mathrm{mi}^{-2}$. 
Table 3.1: Attributes for each surveyed location used in the USGS Michigan Zone 1 regression equation.

\begin{tabular}{|c|c|c|c|c|c|c|c|c|}
\hline Site & $\begin{array}{c}\text { Drainage } \\
\text { Area }\end{array}$ & $\begin{array}{l}\text { Main } \\
\text { Channel } \\
\text { Slope }\end{array}$ & $\begin{array}{c}\text { Main } \\
\text { Channel } \\
\text { Adjacent to } \\
\text { Swamp }\end{array}$ & $\begin{array}{l}\text { Slenderness } \\
\text { Ratio }\end{array}$ & $\begin{array}{l}100 \mathrm{yr}, 24 \mathrm{hr} \\
\text { Precipitation } \\
\text { intensity }\end{array}$ & $\begin{array}{c}\text { Glacial } \\
\text { Outwash }\end{array}$ & Bedrock & $\begin{array}{c}\text { Glacial } \\
\text { Coarse Till }\end{array}$ \\
\hline units & $\mathrm{mi}^{2}$ & $\%$ & $\%$ & & in $\mathrm{hr}^{-1}$ & $\%$ & $\%$ & $\%$ \\
\hline BUSH01 & 24.1 & 0.24 & 87.2 & 8.0 & 5.8 & 14.1 & 9.3 & 76.6 \\
\hline BUSH06 & 1.6 & 0.69 & 73.9 & 1.5 & 5.8 & 0.0 & 0.0 & 100.0 \\
\hline JESSO & 0.9 & 0.97 & 69.2 & 3.1 & 5.8 & 0.0 & 0.0 & 100.0 \\
\hline MALLARD & 2.8 & 0.39 & 76.7 & 1.2 & 5.8 & 0.0 & 0.0 & 0.0 \\
\hline MITI & 6.1 & 0.50 & 75.7 & 2.3 & 5.8 & 0.0 & 0.0 & 0.0 \\
\hline NBPRO2 & 46.1 & 0.12 & 75.4 & 3.6 & 5.8 & 15.2 & 2.2 & 11.1 \\
\hline NBPR04 & 7.3 & 0.08 & 89.0 & 2.0 & 5.8 & 0.0 & 0.0 & 0.0 \\
\hline PAINTCR & 14.1 & 0.20 & 86.5 & 3.7 & 5.8 & 2.4 & 0.0 & 0.0 \\
\hline UN33 & 0.5 & 0.35 & 69.9 & 3.9 & 5.8 & 0.0 & 0.0 & 100.0 \\
\hline UNWINS & 0.5 & 0.39 & 65.2 & 2.9 & 5.8 & 0.0 & 0.0 & 0.0 \\
\hline WINS & 2.6 & 0.25 & 90.2 & 4.8 & 5.8 & 0.0 & 0.0 & 0.0 \\
\hline
\end{tabular}


Table 3.2: Estimated discharge at given return intervals across the surveyed sites in the North Branch.

\begin{tabular}{|c|c|c|c|c|c|c|c|c|}
\hline Site & $\mathrm{Q} 2\left(\mathrm{ft}^{3} \mathrm{~s}^{-1}\right)$ & Q5 $\left(\mathrm{ft}^{3} \mathrm{~s}^{-1}\right)$ & $\mathrm{Q} 10\left(\mathrm{ft}^{3} \mathrm{~s}^{-1}\right)$ & $\mathrm{Q} 25\left(\mathrm{ft}^{3} \mathrm{~s}^{-1}\right)$ & $\mathrm{Q} 50\left(\mathrm{ft}^{3} \mathrm{~s}^{-1}\right)$ & $\mathrm{Q} 100\left(\mathrm{ft}^{3} \mathrm{~s}^{-1}\right)$ & $\mathrm{Q} 200\left(\mathrm{ft}^{3} \mathrm{~s}^{-1}\right)$ & $\mathrm{Q} 500\left(\mathrm{ft}^{3} \mathrm{~s}^{-1}\right)$ \\
\hline BUSH01 & 205 & 308 & 375 & 471 & 551 & 635 & 710 & 823 \\
\hline BUSH06 & 32 & 55 & 71 & 95 & 116 & 140 & 162 & 196 \\
\hline JESSO & 18 & 31 & 40 & 54 & 66 & 79 & 92 & 111 \\
\hline MALLARD & 42 & 67 & 85 & 112 & 134 & 159 & 181 & 215 \\
\hline MITI & 82 & 132 & 165 & 215 & 257 & 304 & 345 & 409 \\
\hline NBPR02 & 286 & 426 & 516 & 645 & 750 & 863 & 962 & 1,111 \\
\hline NBPR04 & 67 & 104 & 128 & 164 & 192 & 224 & 252 & 295 \\
\hline PAINTCR & 112 & 172 & 212 & 269 & 316 & 368 & 413 & 482 \\
\hline UN33 & 10 & 16 & 20 & 27 & 32 & 38 & 44 & 53 \\
\hline UNWINS & 9 & 14 & 17 & 23 & 27 & 32 & 36 & 43 \\
\hline WINS & 30 & 47 & 58 & 74 & 88 & 103 & 116 & 137 \\
\hline
\end{tabular}


Eight of the 11 modeled culverts exceeded a headwater depth to culvert diameter (HW/D) ratio of 1 at discharges with return periods less than 500 years (Table 3.3). Failure discharge (Qtop) ranged from $2 \mathrm{ft}^{3} \mathrm{~s}^{-1} \mathrm{mi}^{-2}$ at PAINTCR to $280 \mathrm{ft}^{3} \mathrm{~s}^{-1} \mathrm{mi}^{-2}$ at BUSH06. Three return intervals exceeded 500 years, and we classified these as $>500$-yr events. The minimum return interval for the failure flows was 1 year. Five of the culverts were predicted to fail at return intervals less than 50 years (Table 3.3).

Table 3.3: Predicted failure discharge (Qtop), specific discharge at failure (qtop), design discharge (Q50), specific design discharge (q50), return interval of failure discharges, and failure condition ratio for each surveyed site in the North Branch.

\begin{tabular}{lcccccc}
\hline Site & $\begin{array}{c}\text { Discharge } \\
\text { at Failure } \\
\text { (Qtop) }\end{array}$ & $\begin{array}{c}\text { Specific } \\
\text { Discharge } \\
\text { at Failure } \\
\text { (qtop) }\end{array}$ & $\begin{array}{c}\text { Design } \\
\text { Discharge } \\
(\mathrm{Q} 50)\end{array}$ & $\begin{array}{c}\text { Specific } \\
\text { Design } \\
\text { Discharge } \\
(\mathrm{q} 50)\end{array}$ & $\begin{array}{c}\text { Failure } \\
\text { Return } \\
\text { Interval }\end{array}$ & $\begin{array}{c}\text { Qtop/ } \\
\text { Q50= } \\
\text { Failure } \\
\text { Ratio }\end{array}$ \\
\hline PAINTCR & 24 & 2 & 316 & 22 & 1 & 0.08 \\
JESSO & 20 & 23 & 66 & 77 & 3 & 0.3 \\
UN33 & 29 & 54 & 32 & 61 & 27 & 0.89 \\
UNWINS & 24 & 49 & 27 & 52 & 34 & 0.9 \\
MITI & 233 & 38 & 257 & 42 & 30 & 0.91 \\
WINS & 97 & 37 & 88 & 34 & 73 & 1.10 \\
MALLARD & 155 & 55 & 134 & 49 & 88 & 1.16 \\
NBPR02 & 1,349 & 29 & 750 & 16 & 210 & 1.8 \\
NBPR04 & 429 & 59 & 192 & 26 & $>500$ & 2.23 \\
BUSH01 & 1,713 & 71 & 551 & 23 & $>500$ & 3.11 \\
BUSH06 & 449 & 280 & 116 & 73 & $>500$ & 3.86 \\
\hline
\end{tabular}

\subsection{Predictors of Culvert Failure}

From linear regression analysis comparing the 61 metrics with culvert failure ratio, seven metrics that compared a culvert measurement with an upstream attribute were identified to have an $\mathrm{R}^{2}$ greater than 0.3 (Table 3.4). Of these metrics, two are shown in Figure 3.3 and 3.4. The first metric is culvert width times main channel length divided by watershed area ((ft $\mathrm{xft})$ / $\left.\mathrm{ft}^{2}\right)\left(\mathrm{R}^{2}=0.70\right)$ (Metric a, Table 3.4), where main channel length is the distance of the major 
contributing tributary upstream of the crossing. Total channel length (i.e. Metric c) is the combined length of every contributing tributary upstream of the crossing. This metric implies that failure condition is more likely when a narrower culvert is placed at a location with a relatively wide mean upstream watershed width (Figure 3.3).

The second metric that correlated strongly with failure ratio is culvert width divided by bankfull width (ft / ft) $\left(R^{2}=0.37\right)$ (Metric $g$, Table 3.4), which represents the degree of channel constriction. This metric implies that when the channel is constricted by a culvert, the probability of failure increases. Five other metrics that compare a culvert measurement with upstream attribute with an $\mathrm{R}^{2}$ value greater than 0.3 were also noted (Table 3.4).

Table 3.4: Metrics, units, correlation coefficient, coefficients of determination, and p-value for the metrics that showed strong correlation to culvert failure $\left(R^{2}>0.3\right)$

\begin{tabular}{|c|c|c|c|c|c|}
\hline Metric & Metric description & $\begin{array}{l}\text { Units in } \\
\text { equation }\end{array}$ & $\mathrm{R}$ & $\mathrm{R}^{2}$ & $P$ \\
\hline a & culvert width $\mathrm{x}$ main channel length / watershed area & $(\mathrm{ft} \times \mathrm{ft}) / \mathrm{ft}^{2}$ & 0.84 & 0.70 & 0.07 \\
\hline$b$ & culvert width $\mathrm{x}$ hydraulic length / watershed area & $(\mathrm{ft} x \mathrm{ft}) / \mathrm{ft}^{2}$ & 0.80 & 0.64 & 0.09 \\
\hline e & culvert length $\mathrm{x}$ total channel length / watershed area & $(\mathrm{ft} x \mathrm{ft}) / \mathrm{ft}^{2}$ & 0.68 & 0.47 & 0.15 \\
\hline$f$ & culvert width / hydraulic length & $\mathrm{ft} / \mathrm{ft}$ & 0.67 & 0.45 & 0.21 \\
\hline g & culvert width / bankfull width & $\mathrm{ft} / \mathrm{ft}$ & 0.61 & 0.37 & 0.08 \\
\hline $\mathrm{h}$ & culvert length $x$ total channel length / watershed area & $(\mathrm{ft} \times \mathrm{ft}) / \mathrm{ft}^{2}$ & 0.61 & 0.37 & 0.06 \\
\hline i & culvert inlet area / watershed storage area & $\mathrm{ft}^{2} / \mathrm{ft}^{2}$ & 0.60 & 0.36 & 0.29 \\
\hline
\end{tabular}




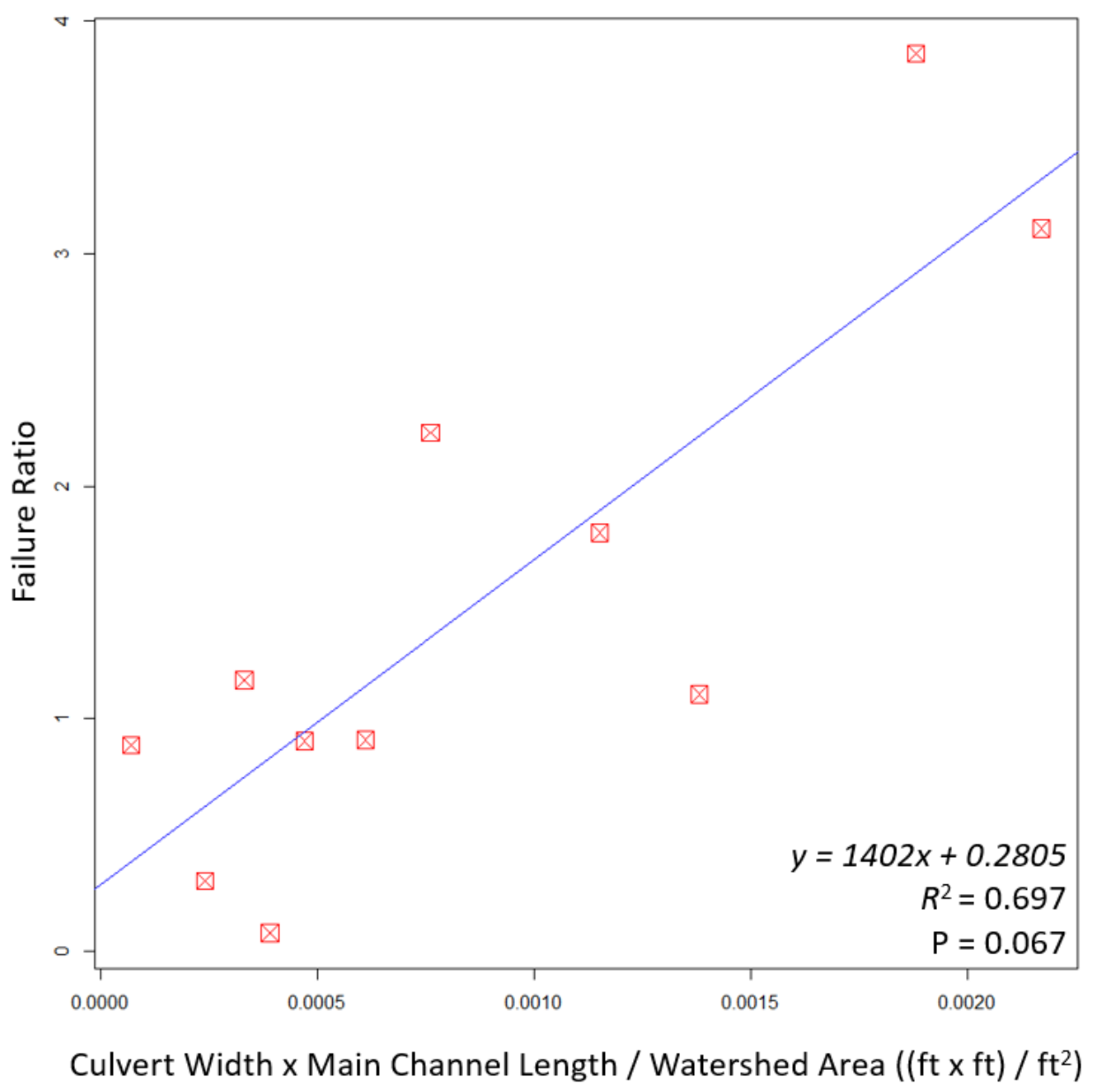

Figure 3.3: Linear regression between failure ratio and metric a (culvert width $\mathrm{x}$ main channel length / watershed area $\left.\left(\mathrm{ft} x \mathrm{ft} / \mathrm{ft}^{2}\right)\right)$, for the sample of 11 surveyed sites. 


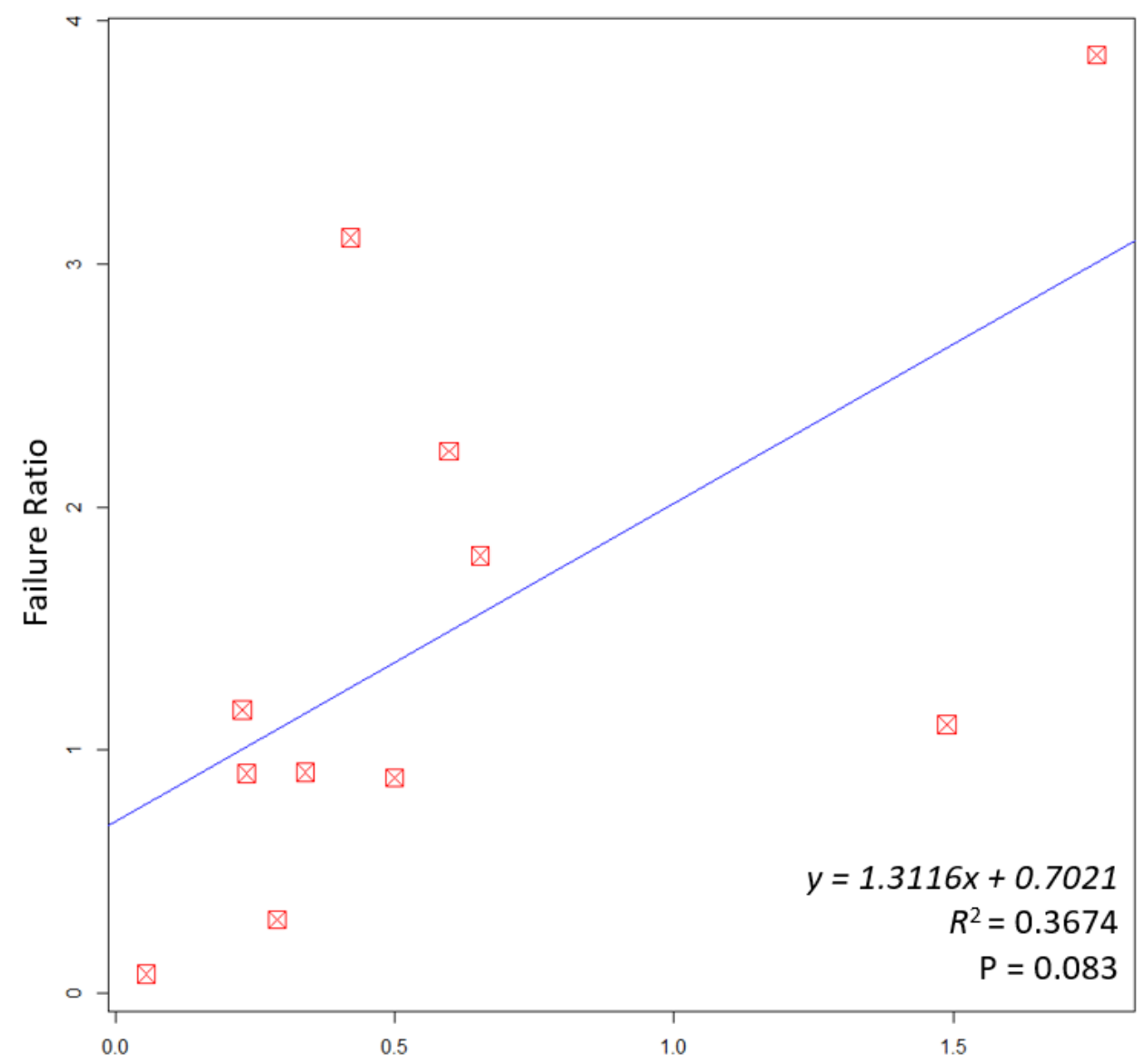

Culvert Width / Bankfull Width $(\mathrm{ft} / \mathrm{ft})$

Figure 3.4: Linear regression between failure ratio and metric g (culvert width / bankfull width (ft / $\mathrm{ft}$ )), for the sample of 11 surveyed sites.

Multiple regression revealed the following variables have the highest ability to explain the variability of modeled culvert failures: culvert volume $\left(\mathrm{ft}^{3}\right)\left(\mathrm{R}^{2}=0.67\right)$ among culvert measurements (Appendix F); bankfull width $(\mathrm{ft})$ among upstream bankfull measurements $\left(\mathrm{R}^{2}=\right.$ 0.03) (Appendix G). Upstream main channel length (mi) correlated highest with the culvert failure ratios $\left(R^{2}=0.11\right)$, and watershed area $\left(\mathrm{mi}^{2}\right)\left(R^{2}=0.05\right)$ upstream the culvert was also used in the multiple regression analysis (Appendix E). Our linear analysis created a model with a multiple $R^{2}$ value of 0.90 , and a combined $p$-value of 0.004 (Table 3.6). 
Table 3.6: Independent variables, individual and combined $\mathrm{R}^{2}$ and $\mathrm{p}$-values for a multiple linear regression model used to predict culvert failure ratio.

\begin{tabular}{ccc}
\hline Independent variable & $\mathrm{R}^{2}$ & $\mathrm{p}$-value \\
\hline Culvert volume $\left(\mathrm{ft}^{3}\right)$ & 0.67 & 0.001 \\
Bankfull width $(\mathrm{ft})$ & 0.03 & 0.56 \\
Main channel length $(\mathrm{ft})$ & 0.11 & 0.83 \\
Watershed Area $\left(\mathrm{mi}^{2}\right)$ & 0.05 & 0.09 \\
\hline Combined & 0.90 & 0.004 \\
\hline
\end{tabular}

The resulting equation from this regression was:

$$
y=0.504+0.0009 C_{V}-0.005 B_{W}+0.0233 M_{L}-0.054 W_{A} \ldots \ldots \ldots . . \text { Equation } 5
$$

Where $\mathrm{y}$ is the failure ratio, $\mathrm{C}_{\mathrm{v}}$ is the culvert volume $\left(\mathrm{ft}^{3}\right), \mathrm{B}_{\mathrm{w}}$ is bankfull width ( $\mathrm{ft}$ ), $\mathrm{M}_{\mathrm{L}}$ is main channel length $(\mathrm{mi})$, and $\mathrm{W}_{\mathrm{A}}$ is the watershed area $\left(\mathrm{mi}^{2}\right)$.

Failure ratios representing failure condition at unsurveyed culverts in the North Branch were predicted from this equation (Table 3.7). Six of the nine unsurveyed sites have an estimated failure condition less than one, and therefore are predicted to fail at a flood return interval less than 50 years (Figure 3.5).

Table 3.7: Model inputs and estimated failure ratio at unsurveyed culverts in the North Branch.

\begin{tabular}{lccccc}
\hline Site & $\begin{array}{c}\text { Culvert } \\
\text { volume }\end{array}$ & $\begin{array}{c}\text { Bankfull } \\
\text { width }\end{array}$ & $\begin{array}{c}\text { Main } \\
\text { channel } \\
\text { length } \\
\left(\mathrm{ft}^{3}\right)\end{array}$ & $\begin{array}{c}\text { Watershed } \\
\text { area }\end{array}$ & $\begin{array}{c}\text { Modeled } \\
\text { Failure } \\
\text { Ratio }\end{array}$ \\
\hline GOLD02 & 1531 & 36.0 & 4.3 & 5.49 & 1.5 \\
GOLD03 & 1578 & 18.4 & 0.3 & 0.48 & 1.8 \\
HOLM02 & 1500 & 15.0 & 2.0 & 4.68 & 1.6 \\
HOLM03 & 284 & 62.0 & 1.4 & 2.81 & 0.3 \\
MITITRIB01 & 41 & 3.5 & 0.3 & 0.71 & 0.5 \\
MITITRIB02 & 38 & 5.6 & 0.9 & 0.64 & 0.5 \\
NBPR10 & 330 & 16.4 & 2.4 & 7.16 & 0.4 \\
SILK01 & 13 & 12.0 & 0.7 & 0.14 & 0.5 \\
UNGOLD01 & 115 & 11.5 & 0.0 & 0.84 & 0.5 \\
\hline
\end{tabular}




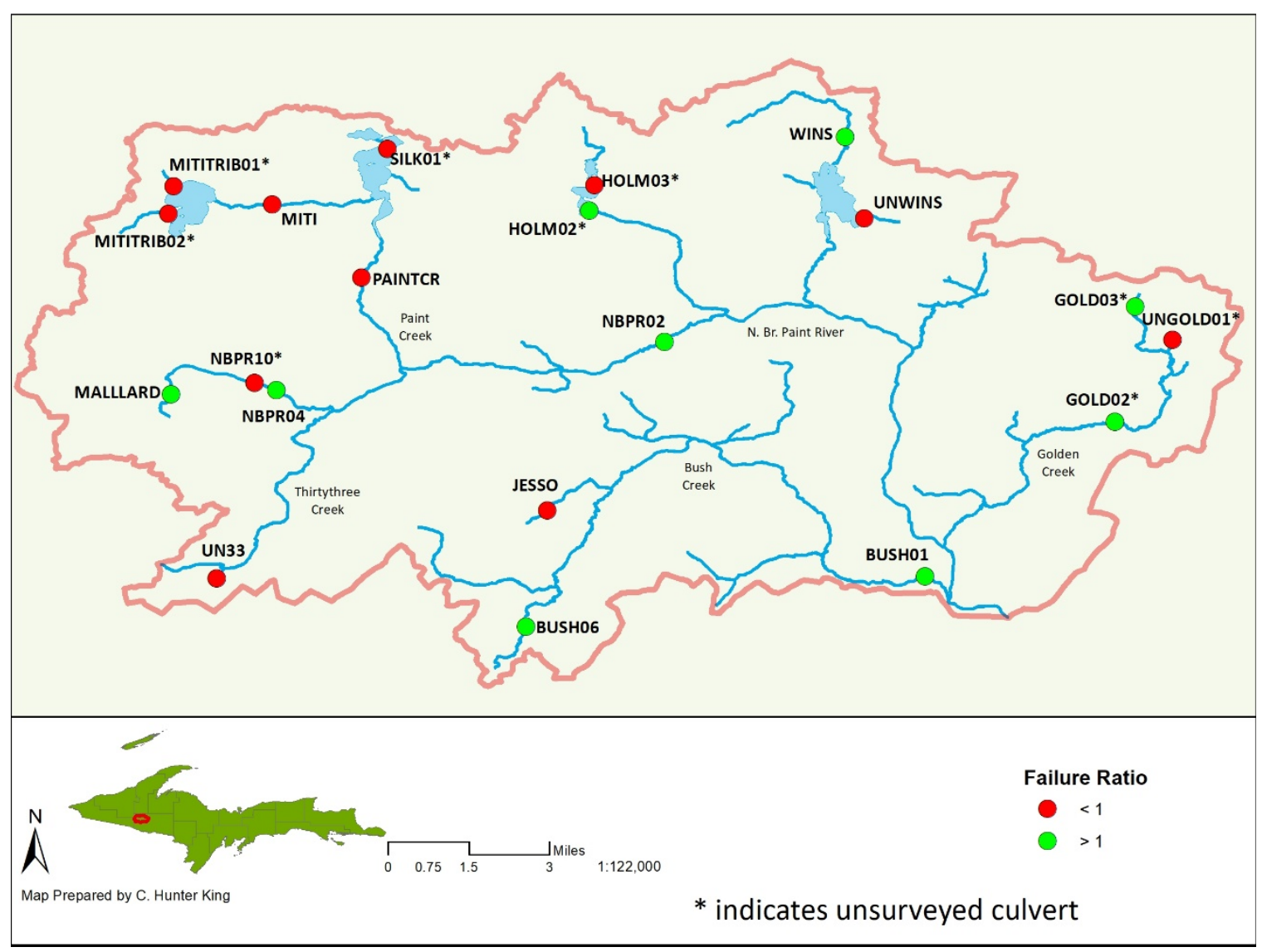

Figure 3.5: Culvert location and predicted failure ratio.

Four of the nine culverts with a passability score of 0 have potential to fail at a discharge less than Q50 (Table 3.8). The three perched culverts in the North Branch, are predicted to fail at a discharge less than Q50 (Table 3.8). 
Table 3.8: Site, passability score, and predicted failure ratio at each culvert in the North Branch. Asterisks $(*)$ indicate perched culverts.

\begin{tabular}{lcc}
\hline Site & $\begin{array}{c}\text { Passability } \\
\text { Score }\end{array}$ & $\begin{array}{c}\text { Predicted } \\
\text { Failure Ratio }\end{array}$ \\
\hline BUSH01 & 0 & 3.1 \\
BUSH06 & 0 & 3.9 \\
GOLD02 & 0 & 1.5 \\
GOLD03 & 0 & 1.8 \\
HOLM02 & 0 & 1.6 \\
HOLM03 & 0 & 0.3 \\
JESSO* & 0 & 0.3 \\
UN33* & 0 & 0.9 \\
UNWINS* & 0 & 0.9 \\
MALLLARD & 0.5 & 1.2 \\
MITI & 0.9 & 0.9 \\
MITITRIB01 & 0.9 & 0.5 \\
MITITRIB02 & 0.9 & 0.5 \\
NBPR02 & 0.9 & 1.8 \\
NBPR04 & 0.9 & 2.2 \\
NBPR10 & 0.9 & 0.4 \\
PAINTCR & 0.9 & 0.1 \\
SILK01 & 0.9 & 0.5 \\
UNGOLD01 & 0.9 & 0.5 \\
WINS & 1 & 1.1 \\
\hline
\end{tabular}

\subsection{Economic Implications of a Culvert Replacement in the North Branch}

Cost of replacement $\left(C_{R}\right)$ estimates for surveyed sites in the North Branch are averaged

$\$ 104,090$ in 2017 dollars and ranged from $\$ 13,341$ to $\$ 171,450$. Service costs $\left(C_{S}\right)$ estimated for planned and failed replacements averaged $\$ 20,818$ and $\$ 31,227$, respectively, across sites

(Table 3.9). 
Table 3.9: Total cost of replacement $\left(C_{R}\right)$, service cost of planned replacement $\left(C_{S P}\right)$, and service cost of failed replacement $\left(\mathrm{C}_{\mathrm{SF}}\right)$ for each site.

\begin{tabular}{lccc}
\hline Site & $\begin{array}{c}\text { Total Cost of } \\
\text { Replacement } \\
\left(C_{R}\right)\end{array}$ & $\begin{array}{c}\text { Service cost of } \\
\text { Planned } \\
\text { Replacement } \\
\left(20 \% \text { of } C_{R}\right)\left(C_{S P}\right)\end{array}$ & $\begin{array}{c}\text { Service cost of } \\
\text { Failed } \\
\text { Replacement } \\
\left(30 \% \text { of } C_{R}\right)\left(C_{\text {SF }}\right)\end{array}$ \\
\hline BUSH01 & $\$ 171,450$ & $\$ 34,290$ & $\$ 51,435$ \\
BUSH06 & $\$ 32,526$ & $\$ 6,505$ & $\$ 9,758$ \\
JESSO & $\$ 107,924$ & $\$ 21,585$ & $\$ 32,377$ \\
MALLARD & $\$ 171,450$ & $\$ 34,290$ & $\$ 51,435$ \\
MITI & $\$ 49,635$ & $\$ 9,927$ & $\$ 14,890$ \\
NBPR02 & $\$ 171,450$ & $\$ 34,290$ & $\$ 51,435$ \\
NBPR04 & $\$ 114,300$ & $\$ 22,860$ & $\$ 34,290$ \\
PAINTCR & $\$ 171,450$ & $\$ 34,290$ & $\$ 51,435$ \\
UN33 & $\$ 27,167$ & $\$ 5,433$ & $\$ 8,150$ \\
UNWINS & $\$ 114,300$ & $\$ 22,860$ & $\$ 34,290$ \\
WINS & $\$ 13,341$ & $\$ 2,668$ & $\$ 4,002$ \\
\hline
\end{tabular}

User delay costs $\left(C_{D}\right)$ were $\$ 599$ for a planned culvert replacement lasting two days and $\$ 2,996$ for a failed culvert replacement, lasting 10 days (Table 3.10).

Table 3.10: Inputs and associated costs to estimate $C_{D P}$ and $C_{D F}$ from Equation 1 and Equation 2.

\begin{tabular}{llcc}
\hline Input & Planned & $\begin{array}{c}\text { Failure } \\
\text { Delay Cost } \\
\left(C_{D P}\right)\end{array}$ & $\begin{array}{c}\text { Delay Cost } \\
\left(C_{D F}\right)\end{array}$ \\
\hline$T$ & Daily Traffic & 10 & 10 \\
$H$ & Delay Time (hours) & 1 & 1 \\
$D$ & Days of Replacement & 2 & 10 \\
$C_{P}$ & Personnel $\left(\$\right.$ hr $\left.^{-1}\right)$ & $\$ 24$ & $\$ 24$ \\
$V_{P}$ & \% Passenger Traffic & 97 & 97 \\
$V_{O}$ & Occupancy & 1.2 & 1.2 \\
$C_{F}$ & Freight $\left(\$\right.$ hr $\left.^{-1}\right)$ & $\$ 70$ & $\$ 70$ \\
$V_{F}$ & \% Truck Traffic & 3 & 3 \\
\hline$C_{D}$ & Cost Estimate & $\$ 599$ & $\$ 2,996$ \\
\hline
\end{tabular}

Cost of sediment replacement $\left(C_{G}\right)$ ranged from $\$ 377$ to $\$ 5,945$ at surveyed sites in the North Branch (Table 3.11). Cost of sediment removal $\left(C_{E}\right)$ from the downstream channel averaged $\$ 6,017$ and ranged from $\$ 4,485$ to $\$ 9,285$ across sites (Table 3.11). 
Table 3.11: Sediment loss, fill replacement cost $\left(C_{G}\right)$, and sediment removal cost $\left(C_{E}\right)$ at surveyed sites.

\begin{tabular}{lccc}
\hline Site & $\begin{array}{c}\text { Sediment Loss } \\
\left(\mathrm{yd}^{3}\right)\end{array}$ & $\begin{array}{c}\text { Fill } \\
\text { Replacement } \\
\text { Cost }\left(\mathrm{C}_{\mathrm{G}}\right)\end{array}$ & $\begin{array}{c}\text { Sediment } \\
\text { Removal } \\
\text { Cost }\left(\mathrm{C}_{\mathrm{E}}\right)\end{array}$ \\
\hline BUSH01 & 75 & $\$ 2,175$ & $\$ 6,035$ \\
BUSH06 & 57 & $\$ 1,653$ & $\$ 5,585$ \\
JESSO & 49 & $\$ 1,421$ & $\$ 5,385$ \\
MALLARD & 111 & $\$ 3,219$ & $\$ 6,935$ \\
MITI & 123 & $\$ 3,567$ & $\$ 7,235$ \\
NBPR02 & 205 & $\$ 5,945$ & $\$ 9,285$ \\
NBPR04 & 104 & $\$ 3,016$ & $\$ 6,760$ \\
PAINTCR & 40 & $\$ 1,160$ & $\$ 5,160$ \\
UN33 & 15 & $\$ 435$ & $\$ 4,535$ \\
UNWINS & 25 & $\$ 725$ & $\$ 4,785$ \\
WINS & 13 & $\$ 377$ & $\$ 4,485$ \\
\hline
\end{tabular}

Total cost of a planned culvert replacement $\left(T_{P}\right)$ averaged $\$ 124,963$ and ranged from

$\$ 16,009$ at WINS to $\$ 206,339$ at BUSH01. Total costs of a replacement after failure $\left(T_{F}\right)$ were $11 \%$ to $39 \%$ more than $T_{p}$, and averaged $19 \%$ more throughout analyzed sites (Table 3.12). The increase in cost varied with the complexity of the size and number of structures (pipes) at each crossing, and the relative amounts of sediment mobilized at failure. 
Table 3.12: Estimated total planned cost of replacement, total failure cost of replacement, and the percent increase in cost because of culvert failure for each site.

\begin{tabular}{lccc}
\hline Site & $\begin{array}{c}\text { Total Planned } \\
\text { Cost of } \\
\text { Replacement }\left(T_{P}\right)\end{array}$ & $\begin{array}{c}\text { Total Failure } \\
\text { Cost of } \\
\text { Replacement }\left(T_{F}\right)\end{array}$ & $\begin{array}{c}\text { Percent } \\
\text { Increase }\end{array}$ \\
\hline BUSH01 & $\$ 206,339$ & $\$ 234,091$ & $13 \%$ \\
BUSH06 & $\$ 39,032$ & $\$ 49,522$ & $27 \%$ \\
JESSO & $\$ 129,509$ & $\$ 147,108$ & $14 \%$ \\
MALLARD & $\$ 205,740$ & $\$ 233,039$ & $13 \%$ \\
MITI & $\$ 59,562$ & $\$ 75,327$ & $26 \%$ \\
NBPR02 & $\$ 205,740$ & $\$ 238,115$ & $16 \%$ \\
NBPR04 & $\$ 137,160$ & $\$ 158,366$ & $15 \%$ \\
PAINTCR & $\$ 205,740$ & $\$ 229,205$ & $11 \%$ \\
UN33 & $\$ 32,600$ & $\$ 40,287$ & $24 \%$ \\
UNWINS & $\$ 137,160$ & $\$ 154,100$ & $12 \%$ \\
WINS & $\$ 16,009$ & $\$ 22,205$ & $39 \%$ \\
\hline Average & $\$ 124,963$ & $\$ 143,760$ & $19 \%$ \\
\hline
\end{tabular}

Estimated costs of planned replacement for the nine unsurveyed culvert sites in the

North Branch averaged $\$ 127,005$ and ranged from $\$ 14,970$ to $\$ 205,380$. Assuming a $19 \%$

increase in cost to replace each culvert after failure, emergency replacement ranged from

$\$ 17,811$ to $\$ 245,115$ at the unsurveyed culverts in the North Branch (Table 3.13).

Table 3.13: Estimates for total planned and failure costs of replacement at unsurveyed culverts in the North Branch.

\begin{tabular}{lcc}
\hline Site & $\begin{array}{c}\text { Total Planned } \\
\text { Cost of } \\
\text { Replacement }\end{array}$ & $\begin{array}{c}\text { Total Failure } \\
\text { Cost of } \\
\text { Replacement }\end{array}$ \\
\hline UNGOLD & $\$ 137,519$ & $\$ 163,648$ \\
GOLD02 & $\$ 205,979$ & $\$ 245,115$ \\
GOLD03 & $\$ 137,519$ & $\$ 163,648$ \\
HOLM02 & $\$ 137,519$ & $\$ 163,648$ \\
HOLM03 & $\$ 205,979$ & $\$ 245,115$ \\
MITITRIB01 & $\$ 14,968$ & $\$ 17,811$ \\
MITITRIB02 & $\$ 28,527$ & $\$ 33,947$ \\
SILK02 & $\$ 137,519$ & $\$ 163,648$ \\
NBPR10 & $\$ 137,519$ & $\$ 163,648$ \\
\hline Average & $\$ 127,005$ & $\$ 151,136$ \\
\hline
\end{tabular}




\section{$4 \quad$ Discussion}

\subsection{Predictors of Culvert Failure}

As storms with increased intensity are occurring more often throughout the Great Lakes Basin (Changnon and Kunkel, 1995), the probability of culvert failure because of insufficient capacity is also increasing, and therefore prioritizing stream crossings based on potential risk of failure should be considered. Wissink et al. (2005) argue that if a published review of culvert failures were to take place, the mechanisms of failure may be just as numerous as the number of failures. The interaction between culvert attributes, road composition, soil, upstream watershed conditions, and climate make failure identifiers difficult to quantify, especially across large areas and varying climate. Through multiple regression, this study identified that the individual attributes of culvert volume, upstream bankfull width, upstream main channel length, and upstream watershed area were good predictors of failure conditions at culverts. Though the equation in this study (Equation 5) may be over-fit and will need more data to develop a reliable model. Using culvert and upstream measurements that fall within the range of those in the North Branch multiple regression, failure ratios can be predicted at culverts in other watersheds in the northern Great Lakes Basin. Metric a (Table 3.4) can be used to estimate failure risk at a culvert. When applied across a sample of culverts, Metric a will indicate the relative probability that a culvert will fail under a commonly used design discharge (Q50). Through comparing culvert width to upstream bankfull width (metric g, Table 3.4), or constriction ratio, potential failure conditions can also be predicted at a culvert. For example, PAINTCR had a constriction ratio of 0.056 and a predicted failure return interval of 1 year, while at the other end of the range in the North Branch, BUSHO6 had a constriction ratio of 1.76 and a predicted failure return interval of $>500$ years (Table 3.4 ). Applying this simple analysis across a broad population 
of culverts will aid in prioritization for risk of failure, as the culverts with smaller constriction ratios are at higher risk of failing at closer occurring return interval. After a major flooding event in New England states in 2012, $100 \%$ of culverts located in or near towns with constriction ratios $<0.5$ failed (Gillespie et al., 2014). Although our study watershed was not located in or near a town, there is relationship between constriction ratio, risk of failure, and fish passage throughout watersheds with differing landuse.

These metrics could be used in the screening process for culvert replacement prioritization. By using USDA Forest Service recommendations, such as culverts that simulate the natural stream channel in terms of bankfull width and natural substrate throughout, risk of failure will be reduced at sites where channel constriction is measured (Gubernick et al., 2008). One example of a prioritization based on our results would be to replace culverts with a constriction ratio less than 0.5 with larger or more effective crossings, such as stream simulating culverts. Although stream simulating culverts are normally more costly than traditional culvert designs at implementation (Gillespie et. al., 2014), stream simulation culverts mimic the characteristics of the natural stream and allow unobstructed organism passage. A wide range of flood flows and associated wood and sediment loads are also able to pass through the stream simulation structures (Gubernick et al., 2008; Diebel et al., 2009; Cenderelli et al., 2011).

\subsection{Fish Passability}

The removal or remediation of a potential barrier to aquatic organism passage may increase stream connectivity. Observations from this study infer that passability and risk of failure can be associated in the North Branch. Nine culverts had passability ratings of 0 , and of the nine, four were predicted to fail within the 50-year flood return interval. The other 11 culverts with passability rank of $0.5,0.9$, and 1 had a predicted failure flood return that ranged from the 1 year to $>500$ year. The three surveyed culverts that had perched outlets (passability 
0) also predicted Qtop return periods of less than 35-years, therefore a perched culvert should be ranked highest for replacement in terms of both fish passability and risk of failure.

The majority of culverts that are passable (score $0.5,0.9,1$ ) were scored 0.9 , indicating that the culverts are barriers to fish only at high flows. Due to predictions of intense precipitation events occurring more often in the Great Lakes, these culverts will be less passable more often throughout the year (Kunkel, 2003; Groisman et al., 2005; Brandt et al., 2010; d'Orgeville et al., 2014). Fish passability scores are typically acquired from the field during a single visit, and often during periods of lower flow when streams are accessible .These one-time ratings may not be an accurate predictor of fish passability throughout the year or during periods of high flow. Spring run-off is necessary for many important fish in the Great Lakes to reach suitable spawning habitat, including; steelhead, walleye, sturgeon, and white sucker (Kling et. al, 2003). These seasonal high flows associated with snowmelt may decrease passability at a culvert with score 0.9 to 0.5 or even 0 . Partial plugging due to ice in the culvert, or beaver activity may also impact passability scores. If fish passability is the overarching rationale for replacing a culvert, focal fish taxon population densities should be referred to in different stream reaches with impassable barriers (McKay et al., 2016). If more of the focal taxon occurs in a particular reach, or if there is documented decline in fish populations, we suggest that a more detailed survey and analysis of stream impairments be conducted. It is possible that connectivity could be addressed by prioritizing low passability or high failure risk culverts with improved designs. However, other negative pressure may also be affecting local fish populations, and this can only be accurately assessed using more detailed field surveys and analysis. . 


\subsection{Effects of Climate on Culvert Failure}

The regression equations that best predicted flood discharge estimates at the North Branch were established in 1984 (Holtschlag and Crosky, 1984). Even using these relatively dated equations, we found that the 100-yr 24-hr rainfall intensity based on the average from 1944-2012 (NOAA, 2013) was a better predictor of observed discharge in the three reference streams than the intensity derived from the period 1909-1957 (USDC, 1961). This suggests that the climate has shifted sufficiently between these periods to affect the flood frequency response of the streams in the region. USGS regression equations are the most accepted statistical method to estimate flood frequency for ungaged streams (Dawdy et al., 2012) and updating the regression equations may lead to even more accurate flood predictions.

In an analysis by Groisman et al. (2005), Michigan, Wisconsin, Minnesota, Illinois, and Ohio experienced a $20 \%$ increase in the frequency of intense precipitation (upper $0.3 \%$ daily precipitation) from 1893-2002. Kunkel (2003) concludes that 5 year 24 hour storm events have increased $4 \%$ per decade since 1900 . About $85 \%$ of these storm events occurred between the months of May and September with roughly $90 \%$ of the trend attributed to increasing temperatures in the region. By 2050 the median 50-year return precipitation amount in the Great Lakes Basin is projected to increase by $14 \%-29 \%$, increasing potential discharge (d’Orgeville et al., 2014). Total precipitation is projected to increase in the Great Lakes basin during winter months, and Brandt et al. (2010) caution that current precipitation measurements should not be used in hydrologic predictions in the Great Lakes. Acquisition of the annual peak flow distribution from USGS stream gaged data in the culvert prioritization area of interest will make future climate predictions more precise. Because snowmelt is a major hydrologic input in the upper Great Lakes (Wu and Johnston, 2006), models that emphasize winter precipitation predictions should be used to acquire future potential peak discharges. 
One possible extension of this study would be to use predicted regional precipitation increases to recalculate the distribution of discharges using the USGS equations and convey the ratio of discharge at culvert failure to a future Q50. Kling et al. (2003) found that two Great Lakes regionalized general circulation models (PCM and HadCM3) predicted 100-yr 24-hr precipitation events to increase, if not double, by 2100 . An estimated discharge of $1,741 \mathrm{ft}^{3} \mathrm{~s}^{-1}$ is predicted where the North Branch joins the South Branch Paint River for the Q50 event using

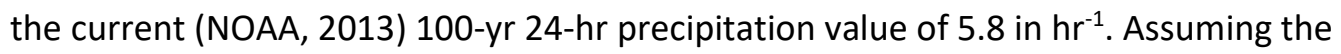
precipitation will double over the next century and all the other coefficients in the USGS regression equations for Michigan remain constant, the calculated future discharge would be $5,139 \mathrm{f}^{3} \mathrm{~s}^{-1}$, nearly three times the current estimate. (Holtschlag and Crosky, 1984, Kling et. al., 2003).

\subsection{Age of Infrastructure and Culvert Failure}

The age of surveyed culvert is one key trait that can lead to culvert failure and was not accounted for in this study. The useful design life for corrugated metal pipe ranges from 35 to 50 years, and concrete ranges from 50-100+ years (Perrin and Jhaveri, 2004). Najafi et al. (2008) conclude that the majority of stream crossings and drainage infrastructure in the USA is nearing, if not already passed, the end of their design life. Culvert failure rates are also high near the beginning of their life due to improper installation or manufacturing problems (Najafi, 2005). If the culvert is installed at erroneous elevation or slope compared with the natural stream conditions, or if the structure does not have adequate bedding material, one major discharge may cause failure within a few years of installation. Thus, the relationship between probability of structural failure and time creates a "bathtub" curve with high probability of culvert failure at installation, low probability of failure during the remainder of the design life, and increased 
probability of failure after the design life has been surpassed (Najafi, 2005). By adding a rank associated with years-post-installation, probability of failure due to culvert age can be included in the prioritization process. For example, age-of-culvert scores could be low for the first $0-5$ years, then increase and be constant for age 6-40 culverts, then decrease back to the original implementation score for culverts that exceed 40 years of age. This age-of- structure score could then be added to the passability score and failure ratio estimated for the culvert. Summing of these scores would provide a simple prioritization ranking where a lower value would indicate a culvert that should be replaced sooner than one with a higher score, though there is less rationale to replace a new culvert, unless there is observable malfunction due to improper installment. For example, a culvert age $0-5$ could have an age-of structure of 0.5 , age $6-40$ could have a score of 1 , and a $40+$ year-old culvert could have a score of 0.1 . Such that, a 31 year old culvert with a failure ratio of 0.8 , and a fish passability score of 0.9 would have a prioritization ranking of 2.7. As that same culvert ages another decade, assuming no changes to failure ratio and passability scores, the prioritization rank would decrease to 1.8. This type of application, across a large number of culverts will provide a ranking system that addresses risk of failure, passability, and age of the culvert.

\subsection{Economic Impact of Single and Multiple Failures}

Costs of individual culvert failure vary due to size of structure(s) and the amount of sediment and fill mobilized from the road prism at failure. Larger storms may road fill wider than downstream bankfull width to mobilize into the downstream channel and floodplain. To accommodate more potential sediment loss, a width estimate greater than downstream bankfull could be used (Equation 4). A suite of assumptions could be used to identify costs attributed to loss of riverine ecosystem service at a culvert failure location (Levine, 2013). This 
study used the cost to remove sediment from the stream channel as a mechanism to estimate this added cost at failure. Loss of recreation, water quality for municipal use, and navigation values are not accounted for, and could be important for particular river systems.

To apply an economic application to river connectivity for fish, a cost benefit analysis could be created where the benefit is stream connectivity and the cost is the net present value investment of the culvert of interest. To acquire the stream connectivity, one could simply multiply the amount of miles upstream of the culvert with the passability score subtracted from one. The net present value could be estimated by subtracting the present value of an emergency culvert replacement from the planned cost of culvert replacement. The output of this cost benefit analysis would be in dollars per mile, and could be used in situations where fish passability is strongly weighted.

Cumulative impacts associated with multiple failures within the watershed from the same storm were not taken into account in the economic analysis of this study. An event producing Q50 would potentially cause 11 of the 20 surveyed culverts to fail, and replacing these would cost \$1.4 million after the emergency using the per-culvert replacement costs. Realistically, a large storm producing multiple failures would increase the cost estimates from this study, which were developed based on the replacement of a single culvert. The majority of the added costs would come from; insufficient availability of labor resulting in added delays and service costs. The delay cost does not account for higher value delay estimates such as emergency vehicle access or response time, or prolonged detours lasting longer than an hour. To create a more accurate estimate of the cost associated with user delay, detour and daily durations can be manipulated in Equation 3 (Section 2.7). Estimates for these added costs are dependent on a suite of assumptions such as, permanent human residency in the watershed, age of residents, and local commerce (Perrin and Jhaveri, 2004). Because of the reliance of the 
delay cost on the population density, estimates of the total cost of a culvert failure would likely increase in areas with greater development. The North Branch is located in Iron County, MI, U.S.A, which has a population density of 9 people per square mile (US Census Bureau A, 2016), which is less than other counties in the northern Great Lakes region such as, for example, Antrim County, MI, U.S.A (48 people per square mile) (US Census Bureau B, 2016). Another unrecognized cost in the individual replacement analysis is the cost of financing, which may not be an issue for single replacements and therefore is an appropriate simplification for single culvert failure analysis. However, for large storms such as the Q50 that would potentially take out 11 culverts in the North Branch, the financing availability and cost may be significant and this could further extend the time needed to complete the repairs.

\subsection{Recommendations}

It is recognized that free flowing freshwater ecosystems are critical and increase the wellbeing of humanity (Brisbane Declaration, 2007). Poff et al. (2015) argue for new water management models that call for collaboration of water resource engineers, conservation ecologists, and stakeholders to engage and collaborate in the decision-making process.

By using either the individual metrics, multiple linear regression or fish passability scoring, a map could be created for a given watershed, similar to Figure 3.5, where a green point indicates a culvert with low risk of failure or high passability, and a red point indicates a culvert with high risk of failure or low passability. By visually representing culverts in space, simple assumptions and decisions can be made pertaining to the amount of stream that would be reconnected with a given replacement. By integrating or associating a prioritization score, such as one described above in Section 4.3, recommendations can be made to remove or replace a culvert based on both fish passability and risk of failure. Culverts with failure ratios close to 1 or 
a combined passability and failure rating in the middle of the group of analyzed culverts could be assessed using more rigorous methods. In these cases, given available time and funds, surveying with a total station and doing hydraulic modeling with a model such as HEC-RAS might help identify culverts that are on the margin of the priority list. If there are river reaches that are more suitable for fish habitat or populations, or where habitat restoration has been made a priority, more weight could be given in the prioritization to fish passability. Regardless of the method of prioritization, if a culvert is targeted for upgrade, the stream simulation design should be considered for the replacement culvert to create more natural hydrologic and ecologic stream dynamics.

Given the small sample size of potential barriers in the North Branch, more analysis on other small subwatersheds would strengthen the predictive ability of the metrics. Also, this study focused on prioritizing potential barriers in relatively undeveloped forests in the northern Great Lakes Basin, and our results should apply to other watersheds with similar attributes. The North Branch has very low developed land, and negligible amount of land used for agriculture as compared to other parts of the northern Great Lakes Basin. Using our approach on other watersheds with higher rates of impervious or agricultural land use would also increase confidence in the metrics we identified as good predictors of the risk of culvert failure at high flows. 


\section{Conclusion}

We estimated the impacts associated with stream crossing infrastructure in low-order streams in Northern Michigan. Because culverts have the greatest risk of failure, we analyzed the economic and ecologic implications of potential culvert failure. We identified all the structures in the North Branch Paint River watershed and applied fish passability ratings and the Great Lakes Road Crossing Inventory Instructions (GLRCII) for each structure. We also calculated the discharge that would cause the headwater to depth ratio to exceed one and the return interval associated with this discharge for a sample of 11 culverts and associated stream segments that were surveyed. This study identified predictors from the relatively easily obtained measurements from the GLRCII and tested their ability to predict potential failure. Two metrics had high predictive ability. The first metric was culvert width times main channel length divided by watershed area $\left((\mathrm{ft} \mathrm{xft}) / \mathrm{ft}^{2}\right)$. This metric implies that failure condition is more likely when a narrower culvert is placed at a location with a relatively wide mean upstream watershed width. The second metric that correlated strongly with failure is culvert width divided by bankfull width, which represents the degree of channel constriction. This metric implies that as the upstream channel is constricted by a culvert inlet, the probability of failure increases. We estimated the cost of culvert replacement following failure would average $19 \%$ more than planned culvert replacements. By applying this analysis of the risk of failure in the prioritization process for culvert replacements, potential economic and environmental costs could be avoided, particularly as storms become more intense in the Great Lakes Basin as the climate changes. 


\section{References}

Banach, D. M., Brooks, C. N., Fedora, M. A. (2016). Using multitemporal imagery to improve mapping and inventory of forested roads in Michigan's Upper Peninsula. Transportation Research Board, 95th Annual Meeting, 2580.

Biswas, A., \& Tortajada, C. (2001). Development and large dams: a global perspective. Water Resources Development. v. 17. p. 9-21.

Bowler, D. E., \& Benton, T. G. (2005). Causes and consequences of animal dispersal strategies: relating individual behaviour to spatial dynamics. Biological Reviews. v. 80. i. 2. p. 205-225.

Brandt, S. A. (2000). Classification of geomorphological effects downstream of dams. Catena. v. 40. i. 4. p. $375-401$.

Brisbane Declaration. (2007). The Brisbane Declaration: Environmental flows are essential for freshwater ecosystem health and human well-being. Declaration of the 10th International River Symposium and International Environmental Flows Conference, 1-7.

Brunner, G. W. (2016). HEC-RAS River Analysis System - Hydraulic Reference Manual, Version 5.0, (February), 547. Institute for Water Resources, Hydrologic Engineering Center. Davis, CA, U.S.A.

Bureau of Labor Statistics (BLS). U.S. Department of Labor. Occupational Outlook Handbook. CPI Inflation Calculator Data Tool. https://www.bls.gov/data/inflation_calculator.htm. Accessed November 22, 2017.

Cadotte, J. (2012). Worst ever Duluth, Minnesota flood causes $\$ 80$ million in damage. Reuters. https://www.reuters.com/article/us-weather-midwest-floods/worst-ever-duluthminnesota-flood-causes-80-million-in-damage-idUSBRE85K1Q720120621. Accessed December 2, 2017.

Cafferata, P., Spittler, T., Wopat, M., Bundros, G., \& Flanagan, S. (2004). Designing Watercourse Crossings for Passage of 100 -year Flood Flows, Wood, and Sediment. State of California. The Resources Agency. Department of Forestry and Fire Protection.

Cenderelli, D. A., Clarkin, K., Gubernick, R. A., \& Weinhold, M. (2011). Stream Simulation for Aquatic Organism Passage at Road-Stream Crossings. Transportation Research Record: Journal of the Transportation Research Board. v. 2203. p. 36-45.

Changnon, B. S. A., \& Kunkel, K. E. (1995). Climate-related fluctuations in Midwestern floods during 1921-1985. Journal of Water Resources Planning and Management. v. 121. p. 326334.

Collier, M. P., Webb, R. H., \& Andrews, E. D. (1998). Experimental Flooding in Grand Canyon. Scientific American. p. 82-89 
Cowardin, L. M., V. Carter, F. C. Golet, E. T. LaRoe. (1979). Classification of wetlands and deepwater habitats of the United States. U. S. Department of the Interior, Fish and Wildlife Service, Washington, D.C.

d'Orgeville, M., Peltier, W. R., Erler, A. R., \& Gula, J. (2014). Climate change impacts on Great Lakes Basin precipitation extremes. Journal of Geophysical Research: Atmospheres. v. 119. p. 10799-10812.

Dawdy, D. R., Griffis, V. W., \& Gupta, V. K. (2012). Regional Flood-Frequency Analysis: How We Got Here and Where We Are Going. Journal of Hydrologic Engineering. v. 17. i. 9. p. 953959.

U.S. Army Corps of Engineers. (2016). Hydraulic Engineering Center-River Analysis System 5.0.3. (HEC_RAS). Institute for Water Resources, Hydrologic Engineering Center. Davis, CA, U.S.A.

Diebel M., Fedora M., C. S. (2009). Prioritizing Road Crossing Improvement to Restore Stream Connectivity for Stream-Resident Fish. Economics of Mitigation. p. 647-660.

Diebel, M. W., Fedora, M., Cogswell, S., \& O'Hanley, J. R. (2014). Effects of Road Crossings on Habitat Connectivity For Stream-resident Fish. River Research and Applications.

Farrand W.R., Bell, D.L., (1982). Digital version of Quaternary Geology maps of northern and southern Michigan. Department of Geological Sciences, University of Michigan. Geological Survey Division, Michigan Department of Environmental Quality. Division Geographic Information Services Unit, Resource Mapping and Aerial Photography, Michigan Department of Natural Resources.

FEMA. (2012). Minnesota Severe Storms and Flooding. https://www.fema.gov/disaster/4069.

FHWA. (2012). Hydraulic Design of Highway Culverts. U.S. Department of Transportation, Publication No. FHWA-HIF-12-026 (Third Edition).

Fitzgerald, J., \& Clifton, C. (1997). Flooding, land use, and watershed response in the Blue Mountains of northeastern Oregon and southeastern Washington. U.S. Environmental Protection Agency, USDA Forest Service, 1-9.

Foltz, R. B., Yanosek, K. A., \& Brown, T. M. (2008). Sediment concentration and turbidity changes during culvert removals. Journal of Environmental Management. v. 87. i. 3. p. 329-340.

GLRSCII. (2011). Great Lakes Road Stream Crossing Inventory Instructions U.S. Forest Service, U.S. Fish and Wildlife Service, Michigan DNR, Wisconsin DNR, Huron Pines, Conservation Resource Alliance, Michigan Technological University. p. 1-19. http://www.michigan.gov/dnr/0,4570,7-153-10364_52259_55492---,00.html. Accessed December 2, 2017. 
Gibson, R. J., Haedrich, R. L., \& Wernerheim, C. M. (2005). Loss of Fish Habitat as a Consequence of Inappropriately Constructed Stream Crossings. Fisheries. v. 30. p. 10-17.

Gillespie, N., Unthank, A., Anderson, P., Campbell, L., Gubernick, R., Weinhold, M., ... Kirn, R. (2014). Flood Effects on Road-Stream Crossing Infrastructure: Economic and Ecological Benefits of Stream Simulation Designs. Fisheries. v. 39. i. 2.p. 62-76.

Graning, A., \& Hluchan, R. (2012). Summary of Duluth flash flood event, June 19-20, 2012, 5 , http://www.crh.noaa.gov/images/dlh/StormSummaries. Accessed December 2, 2017.

Groisman, P. Y., Knight, R. W., Easterling, D. R., Karl, T. R., Hegerl, G. C., \& Razuvaev, V. N. (2005). Trends in intense precipitation in the climate record. Journal of Climate. v. 18. i. 9. p. 13261350 .

Gubernick, R., Cenderelli, D., Bates, K., Johanson, D., \& Jackson, S. (2008). Stream Simulation : An Ecological Approach to Providing Passage for Aquatic Organisms at Road-Stream Crossings, 646. National Technology and Development Program. San Dimas, CA. U.S.A.

Hager, W. H., \& Del Giudice, G. (1998). Generalized Culvert Design Diagram. Journal of Irrigation and Drainage Engineering, 124(October), 271-274.

Hicks, K., Sullivan, D. (2008). Culvert Assessments in the Annapolis River Watershed. Clean Annapolis River Project (CARP): Annapolis Royal, Nova Scotia.

Holtschlag, D. J., \& Croskey, H. M. (1984). Statistical Models for Estimating Flow Characteristics of Michigan Streams. U.S. Geological Survey Water-Resources Investigations Report 844207. Lansing, MI, U.S.A.

Homer, C.G., Dewitz, J.A., Yang, L., Jin, S., Danielson, P., Xian, G., Coulston, J., Herold, N.D., Wickham, J.D., and Megown, K. (2015). Completion of the 2011 National Land Cover Database for the conterminous United States-Representing a decade of land cover change information. Photogrammetric Engineering and Remote Sensing, v. 81, no. 5, p. 345-354

Januchowski-Hartley, S. R., McIntyre, P. B., Diebel, M., Doran, P. J., Infante, D. M., Joseph, C., \& Allan, J. D. (2013). Restoring aquatic ecosystem connectivity requires expanding inventories of both dams and road crossings. Frontiers in Ecology and the Environment. v. 11. i. 4. p. 211-217.

Kaeding, D. (2017). Communities, Businesses Continue To Rebuild 1 Year After Northwestern Wisconsin Flooding. Wisconsin Public Radio. https://www.wpr.org/communitiesbusinesses-continue-rebuild-1-year-after-northwestern-wisconsin-flooding. Accessed December 2, 2017. 
Kelly, B. (2012). Wawa floods close highway - Emergency declared. Sault Star. http://www.saultstar.com/2012/10/26/wawa-floods-close-highway--emergency-declared. Accessed December 2, 2017.

King S., O'Hanley JR. (2014). Optimal fish passage barrier removal: revisited. River Research and Applications. v. 31. i. 3. p. 418-428.

Kling, G.W., Hayhoe, K., Johnson, L.B, Magnuson, J.J., Polasky, S., Robinson, S.K., Shuter, B.J., Wander, M.M., Wuebbles, D.J., Zak, D.R, Lindroth, R.L., Moser S.C., Wilson M.L. (2003). Confronting Climate Change in the Great Lakes Region: Impacts on our Communities and Ecosystems. Union of Concerned Scientists, Cambridge, Massachusetts, and Ecological Society of America, Washington, D.C.

Kunkel, K. E., Easterling, D. R., Redmond, K., \& Hubbard, K. (2003). Temporal variations of extreme precipitation events in the United States: 1895-2000. Geophysical Research Letters, v. 30. i. 17. p. 51-54.

Levine, J. (2013). An Economic Analysis of Improved Road-Stream Crossings. The Nature Conservancy.

Lian, Y., \& Yen, B. C. (2003). Comparison of Risk Calculation Methods for a Culvert. Journal of Hydraulic Engineering, v. 129. p. 140-152.

Liriano, S. L., \& Day, R. A. (2001). Prediction of scour depth at culvert outlets using neural networks. Journal of Hydroinformatics. v. 3. i. 4. p. 231-238.

Loomis, J., Kent, P., Strange, L., Fausch, K., \& Covich, A. (2000). Measuring the total economic value of restoring ecosystem services in an impaired river basin: Results from a contingent valuation survey. Ecological Economics, v. 33. p. 103-117.

Mai, V. T., Hoult, N. A., \& Moore, I. D. (2014). Effect of Deterioration on the Performance of Corrugated Steel Culverts. Journal of Geotechnical and Geoenvironmental Engineering. v. 140. p. 04013007-1 - 04013007-11.

McKay, S. K., Cooper, A. R., Diebel, M. W., Elkins, D., Oldford, G., Roghair, C., \& Wieferich, D. (2016). Informing Watershed Connectivity Barrier Prioritization Decisions: A Synthesis. River Research and Applications.

McNeely, C., Finlay, J. C., \& Power, M. E. (2007). Grazer Traits, Competition, and Carbon Sources to a Headwater-Stream Food Web. Published by : Ecological Society of America Ecology. v. 88. i. 2. p. 391-401.

Milly, P. C. D., Wetherald, R. T., Dunne, K. A., \& Delworth, T. L. (2002). Increasing risk of great floods in a changing climate. Nature, 415(6871), 514-517. http://doi.org/10.1038/415514a. 
Moody, A.T., Neeson, T.M., Wangen, S., Dischler, J., Diebel, M.W., Herbert, M., Khoury, M., Yacobson, E., Doran, P.J., Ferris, M.C., O'Hanley, J.R.,Mclntyre, P.B.. (2017). Pet project or best project? Online decision support tools for prioritizing barrier removals in the Great Lakes and beyond. Fisheries. v. 42. p. 57-65.

Mount, C., Norris, S., Thompson, R., Tesch, D. (2011). GIS modeling of fish habitat and road crossings for the prioritization of culvert assessment and remediation. Streamline Watershed Management Bulletin. v.14. i. 2. p. 7-13.

Nagrodski, A., Raby, G. D., Hasler, C. T., Taylor, M. K., \& Cooke, S. J. (2012). Fish stranding in freshwater systems: Sources, consequences, and mitigation. Journal of Environmental Management. v. 103. p. 133-141.

Najafi, M. (2005). Trenchless Technology - Pipeline and Utility Design, Construction and Renewal. McGraw-Hill, New York.

Najafi, A. M., Salem, S., Bhattachar, D., \& Salman, B. (2008). An Assessment Management Approach for Drainage Infrastructure and Culverts (No. MRUTC 06-08). Midwest Regional University Transportation Center, University of Wisconsin, Madison.

National Center for Environmental Information (NCEI). (2017). Global Summary of the Month/Global Summary of the Year (GSOM/GSOY) Paulding, MI. Station USC00206398. 2013-02 to 2017-09.

National Oceanic and Atmospheric Administration (NOAA). (2013). Precipitation-Frequency Atlas of the United States. Precipitation-Frequency Atlas of the United States, 8.

Natural Resources Conservation Service (NRCS). (2017). United States Department of Agriculture. GeoSpatial Data Gateway. Accessed online: May 4, 2016. https://datagateway.nrcs.usda.gov/GDGOrder.aspx

Neeson, TM, AT Moody, JR O'Hanley, MW Diebel, PJ Doran, MC Ferris, T Colling, and PB McIntyre. In review. Aging infrastructure creates conservation opportunities: the case for fish-friendly road crossings.

Nilsson, C., Reidy, C. A., Dynesius, M., \& Revenga, C. (2005). Fragmentation and Flow Regulation of the World's Large River Systems. Science, v. 308. i. 5720. p. 405-408.

O’Shaughnessy, E., Landi, M., Januchowski-Hartley, S. R., \& Diebel, M. (2016). Conservation Leverage: Ecological Design Culverts also Return Fiscal Benefits. Fisheries. v. 41. i. 12. p. 750-757.

Pépino, M., Rodríguez, M. A., \& Magnan, P. (2012). Fish dispersal in fragmented landscapes: A modeling framework for quantifying the permeability of structural barriers. Ecological Applications v. 22. p. 1435-1445. 
Perrin Jr, J., \& Jhaveri, C. S. (2004). The Economic Costs of Culvert Failures. 83rd Annual Meeting of the Transportation Research Board, National Research Council. Washington, DC, U.S.A.

Piehl, B. T., Pyles, M. R., \& Beschta, R. L. (1988). Flow Capacity of Culverts on Oregon Coast Range Forest Roads. Water Resources Bulletin.v. 24. i. 3. p. 631-637.

Poff, N. L., Brown, C. M., Grantham, T. E., Matthews, J. H., Palmer, M. A., Spence, C. M., Baeza, A. (2015). Sustainable water management under future uncertainty with eco-engineering decision scaling. Nature Climate Change, 6(1), 25-34.

R Core Team. (2013). R: A language and environment for statistical computing. $R$ foundation for Statistical Computing, Vienna, Austria. URL http://www.R-project.org/.

Roni, P., Beechie, T. J., Bilby, R. E., Leonetti, F. E., Pollock, M. M., \& Pess, G. R. (2002). A Review of Stream Restoration Techniques and a Hierarchical Strategy for Prioritizing Restoration in Pacific Northwest Watersheds. North American Journal of Fisheries Management, v. 22. p. $1-20$.

RStudio Team (2015). RStudio: Integrated Development for R. RStudio, Inc., Boston, MA URL http://www.rstudio.com/.

Schick, R.S., Lindley, S.T. (2007). Directed connectivity among fish population in a riverine network. Journal of Applied Ecology 44: 1116-1126.

Soil Survey Staff. (2017). Soil Series Classification Database. United States Department of Agriculture, Natural Resources Conservation Service.

https://datagateway.nrcs.usda.gov/GDGOrder.aspx. Accessed June 24, 2017.

Sorrell, R. C. (2010). Computing Flood Discharges for Small Ungaged Watersheds. Michigan Department of Environmental Quality, Water Resources Division. Lansing, MI, U.S.A.

Stanley, E. H., \& Doyle, M. W. (2003). Trading off: the ecological effects of dam removal. Frontiers in Ecology and the Environment. p. 15-22.

State of Michigan. (2014). Center for Shared Solutions and Technology Partnerships. CSS_SDE_ADMIN.ROADS_ALL_MGF_V17. Lansing, MI.

Strahler, A. (1957). Quantitative analysis of watershed morphology. Transactions of the American Geophysical Union. v. 38. i. 6. p. 913-920.

Stedinger, J. R., \& Griffis, V. W. (2011). Getting From Here to Where? Flood Frequency Analysis and Climate. Journal of the American Water Resources Association. v. 47. i. 3. p. 506-513. https://doi.org/10.1111/j.1752-1688.2011.00545.x 
Transportation Research Board (TRB). (2000). Highway Capacity Manual. Fourth Edition. National Research Council, Washington, D.C., 2000.

U.S. Census Bureau A. (2016). QuickFacts: Iron County, Michigan. https://www.census.gov/quickfacts/fact/table/ironcountymichigan/PST045216. Accessed December 4, 2017.

U.S. Census Bureau A. (2016). QuickFacts: Antrim County, Michigan. https://www.census.gov/quickfacts/fact/table/antrimcountymichigan/PST045216. Accessed December 4, 2017.

U.S. Department of Commerce. (USDC). (1961).Weather Bureau. Technical Paper No. 40, Rainfall Frequency Atlas of the United States, for Durations from 30 Minutes to 24 Hours and Return Periods from 1 to 100 Years. U.S. Printing Office. Washington, DC. U.S.A.

U.S. Department of Labor (USDL). (2002). National Compensation Survey: Occupational Wages in the United States. Department of Labor Statistics, United States Department of Labor. Washington, DC, U.S.A.

U.S. Department of Labor. (2017). Bureau of Labor Statistics. CPI Inflation Calculator. https://www.bls.gov/data/inflation_calculator.htm. Accessed October 25, 2017.

U.S. Geological Survey (USGS). (1982). Guidelines Determining for Determining Flood Flow Frequency. Interagency Advisory Committee on Water Data, Bulletin \#17B.

U.S. Geological Survey (USGS A). (2016). National Water Information System data available on the World Wide Web (USGS Water Data for the Nation). https://waterdata.usgs.gov/mi/nwis/inventory/?site_no=04033000. Accessed July 10, 2017.

U.S. Geological Survey (USGS B). (2016). National Water Information System data available on the World Wide Web (USGS Water Data for the Nation).

https://waterdata.usgs.gov/mi/nwis/inventory/?site_no=04031000. Accessed July 10, 2017.

U.S. Geological Survey (USGS C). (2016). National Water Information System data available on the World Wide Web (USGS Water Data for the Nation). https://waterdata.usgs.gov/mi/nwis/inventory/?site_no=04060500. Accessed July 10, 2017.

Walker, J. F., \& Krug, W. R. (2003). Flood-Frequency Characteristics of Wisconsin Streams. U.S. Geological Survey. Water-Resources Investigations Report 03-4250. Reston, VA, U.S.A.

Warren, M. L., \& Pardew, M. G. (1998). Road Crossings as Barriers to Small-Stream Fish Movement. Transactions of the American Fisheries Society, 8487(April), 620-629. 
Williams, G. P., \& Wolman, M. G. (1984). Downstream effects of dams on alluvial rivers. U.S. Geology Survey. Prof. Pap.; 1286. http://doi.org/10.1126/science.277.5322.9j. U.S. Printing Office. Washington, DC. U.S.A.

Wissink, K., McKee, M., Houghtalen, R., \& Sutterer, K. (2005). Simple Rating System for Identification of Failure-Critical Culverts and Small Structures. Journal of the Transportation Research Board, (No. 1928), 226-229.

Wood, P., \& Armitage, P. (1997). Biological Effects of Fine Sediment in the Lotic Environment. Environmental Management, 21(2), 203-17.

Wu, K., \& Johnston, C. A. (2007). Hydrologic response to climatic variability in a Great Lakes Watershed: A case study with the SWAT model. Journal of Hydrology. v. 337. p. 187-199.

Zwiers, F. W., \& Kharin, V. V. (1998). Changes in the extremes of the climate simulated by CGC GCM2 under CO 2 doubling. Journal of Climate, 11(9), 2200-2222. 


\section{$7 \quad$ Appendices}

Appendix A: Great Lakes Road Crossing Inventory Instructions (GLRCII) field data sheet (GLRSCII, 2011):

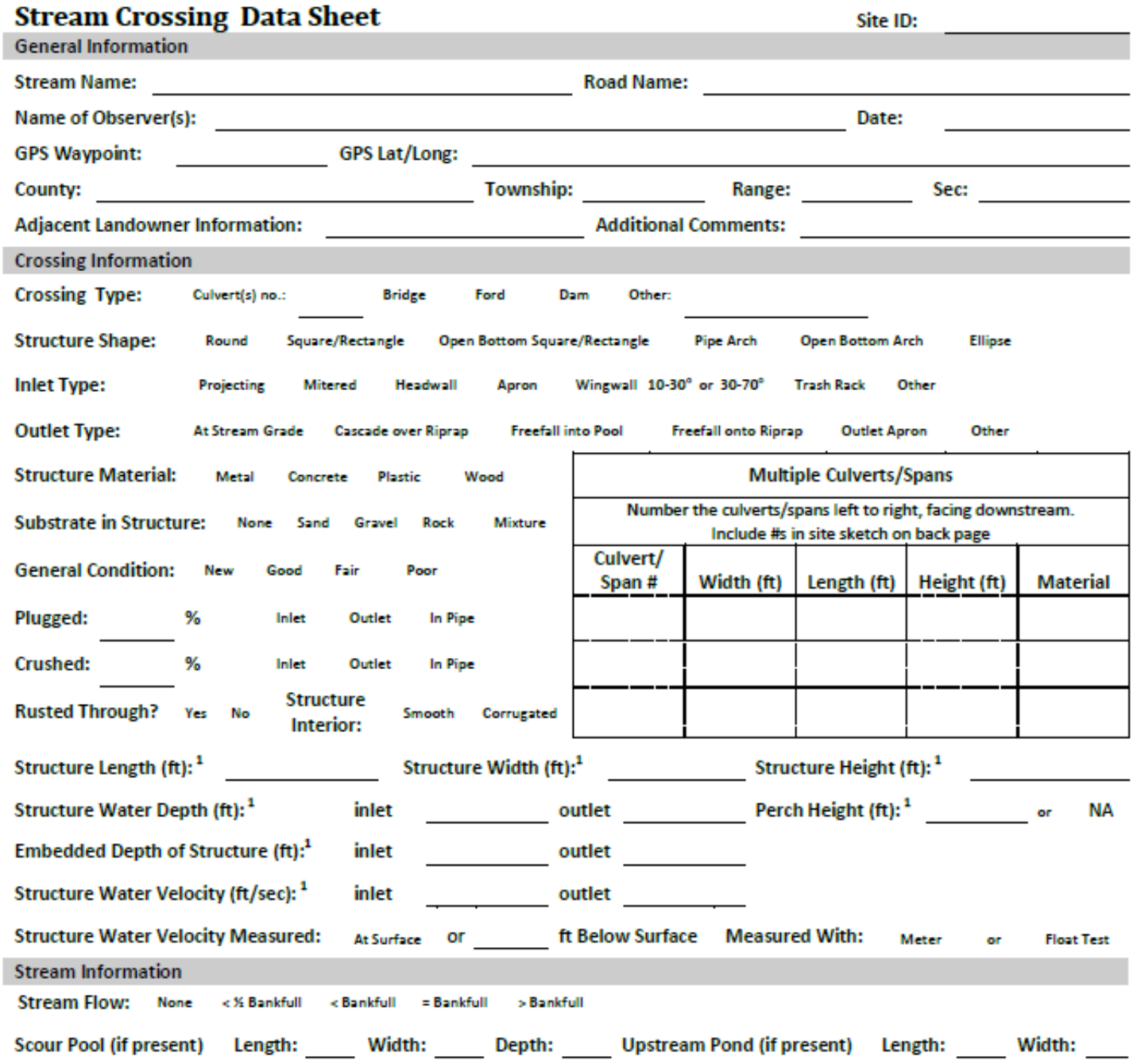

Riffle Information (measured in a riffle outside of zone of influence of crossing)

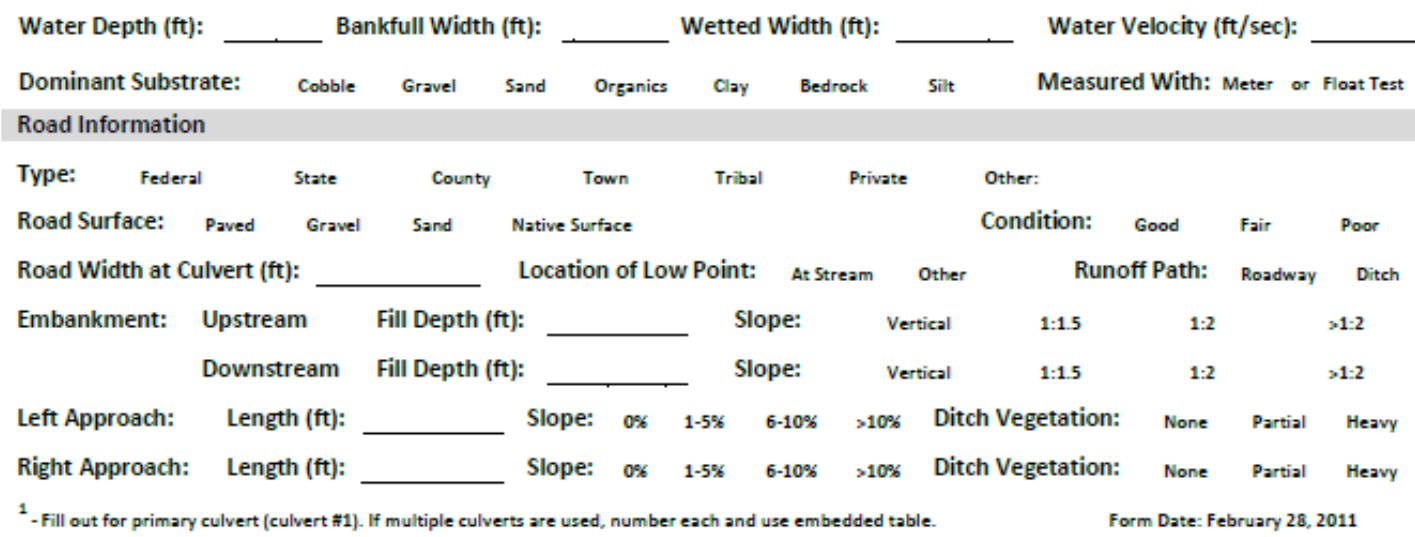


Appendix A continued: Great Lakes Road Crossing Inventory Instructions (GLRCII) field data sheet (GLRSCII 2011):

Erosion Information

Use a new row for each distinct gully/erosion location. Note prominent streambank erosion within 50 feet of crossing.

\begin{tabular}{|c|c|c|c|c|c|c|}
\hline \multirow{2}{*}{$\begin{array}{l}\text { Location of Erosion } \\
\text { Ditch, approach, or streambank } \\
\text { Left or right facing downstream }\end{array}$} & \multicolumn{3}{|c|}{ Erosion Dimensions (ft) } & \multirow{2}{*}{\multicolumn{2}{|c|}{$\begin{array}{l}\text { Eroded Material } \\
\text { Reaching Stream? }\end{array}$}} & \multirow{2}{*}{$\begin{array}{c}\text { Material Eroded } \\
\text { Sand, Silt, Clay, Gravel, Loam, Sandy } \\
\text { Loam or Gravelly Loam. }\end{array}$} \\
\hline & Length & Width & Depth & & & \\
\hline & & & & Yes & No & \\
\hline & & & & Yes & No & \\
\hline & & & & Yes & No & \\
\hline & & & & Yes & No & \\
\hline & & & & Yes & No & \\
\hline
\end{tabular}

If there is erosion occurring, can corrective actions, such as road drainage measures, be installed to address the problem? $\quad \mathrm{Y} \quad \mathrm{N}$

Extent Erosion: Minor Moderate Severe Stabilized

Erosion Notes:

Photos - enter photo number in blank corresponding to location

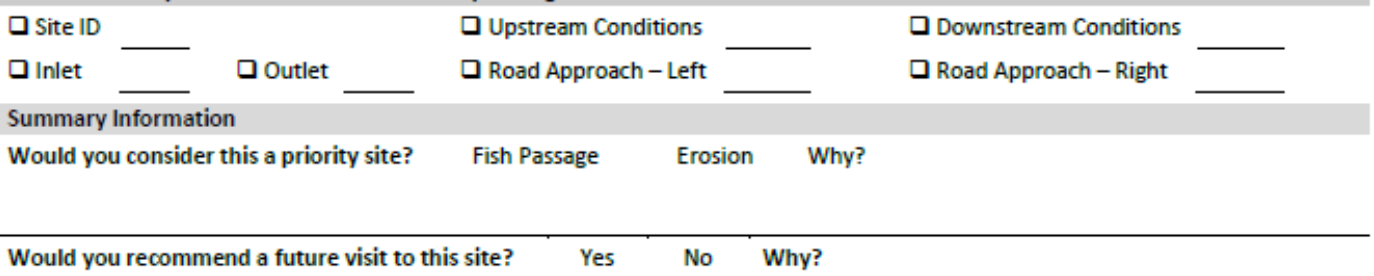

Were any non-native invasive species observed at the site? Yes No If yes, what species were observed?

\section{Site Sketch}

Draw an overhead sketch of crossing. Be sure to mark North on the map and to indicate the direction of flow. Include major

features documented on form, such as erosion sites, multiple culverts, scour pool, impounded water, etc. 
Appendix B:

Table B.1 Cross-watershed comparisons of return interval discharge values ( $\mathrm{ft}^{3} / \mathrm{s}$ ) from Log-Pearson Type 3 (LP3) analysis of observed data; USGS Wisconsin Zone 4 regression equation; USGS Michigan Zone 1 regression (I) using 1961 24-hr precipitation value; USGS Michigan Zone 1 regression (II) using 2013 24-hr precipitation value; and MDEQ method for the Middle Branch Ontonagon River, Black River, and Iron River (USGS, 1982).

\begin{tabular}{|c|c|c|c|c|c|}
\hline $\begin{array}{l}\text { Return } \\
\text { Interval }\end{array}$ & $\begin{array}{l}\text { Log Pearson } \\
\text { Type } 3\end{array}$ & $\begin{array}{c}\text { USGS } \\
\text { Wisconsin } \\
\text { Regression } \\
\end{array}$ & MDEQ & $\begin{array}{c}\text { USGS } \\
\text { Michigan } \\
\text { Regression I }\end{array}$ & $\begin{array}{c}\text { USGS } \\
\text { Michigan } \\
\text { Regression II }\end{array}$ \\
\hline \multicolumn{6}{|c|}{ Mid. Br. Ontonagon River (164 mi²) } \\
\hline 2 & 806 & 733 & 192 & 806 & 902 \\
\hline 5 & 1,162 & 927 & 373 & 1,108 & 1,334 \\
\hline 10 & 1,406 & 1,083 & 549 & 1,299 & 1,605 \\
\hline 25 & 1,726 & 1,287 & 864 & 1,553 & 1,993 \\
\hline 50 & 1,967 & 1,444 & 1,167 & 1,749 & 2,309 \\
\hline 100 & 2,215 & 1,822 & 1,547 & 1,954 & 2,655 \\
\hline \multicolumn{6}{|c|}{ Iron River (92 mi²) } \\
\hline 2 & 459 & 394 & 155 & 380 & 408 \\
\hline 5 & 634 & 525 & 293 & 537 & 602 \\
\hline 10 & 744 & 622 & 424 & 640 & 730 \\
\hline 25 & 878 & 748 & 653 & 778 & 909 \\
\hline 50 & 973 & 843 & 869 & 885 & 1,052 \\
\hline \multicolumn{6}{|c|}{ Black River $\left.\left(184 \mathrm{mi}^{2}\right)\right)$} \\
\hline 2 & 3,784 & 2,008 & 537 & 2,297 & 2,747 \\
\hline 5 & 5,998 & 2,488 & 972 & 3,280 & 4,397 \\
\hline 10 & 7,541 & 2,907 & 1,382 & 3,900 & 5,449 \\
\hline 25 & 9,547 & 3,459 & 2,095 & 4,754 & 7,054 \\
\hline 50 & 11,066 & 3,891 & 2,758 & 5,439 & 8,436 \\
\hline 100 & 12,595 & 4,991 & 3,587 & 6,161 & 10,005 \\
\hline
\end{tabular}


a)

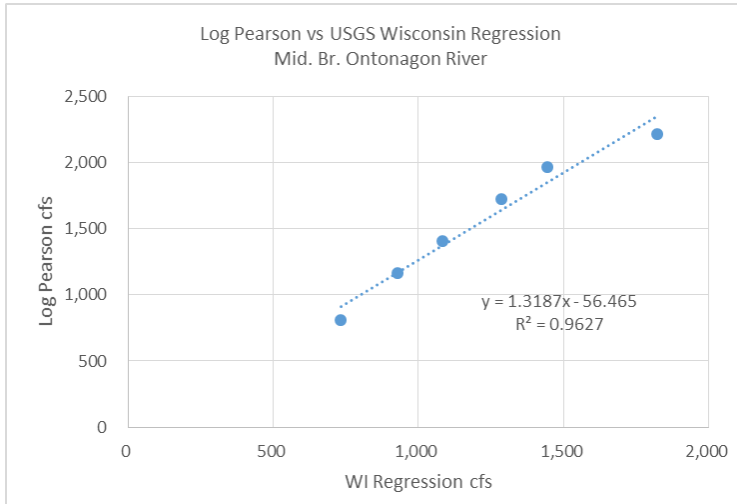

c)

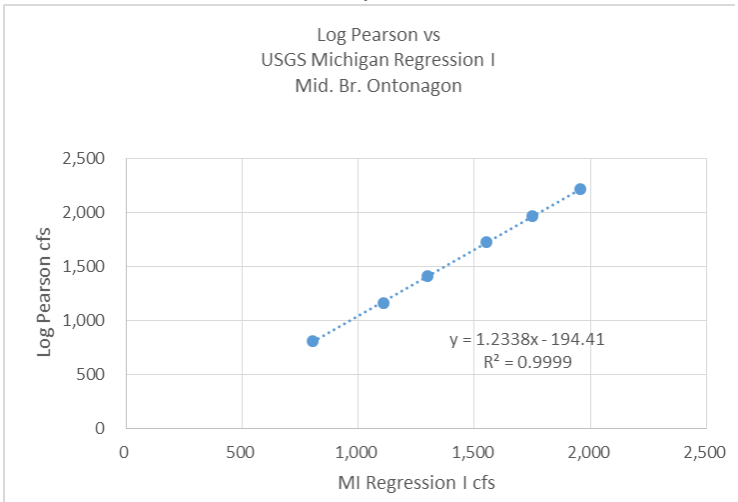

b)

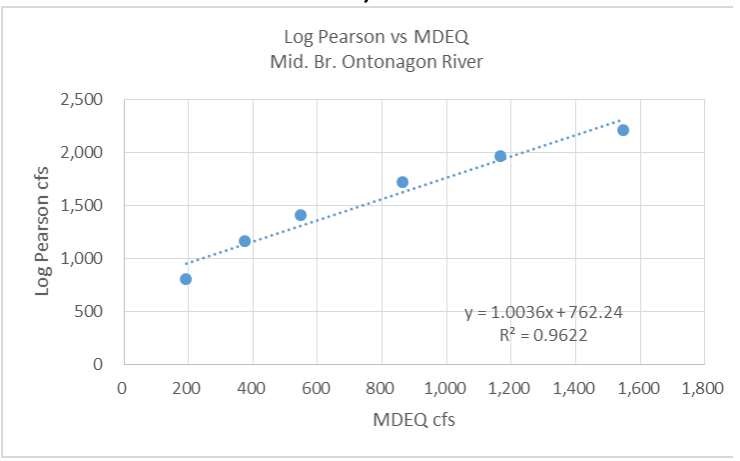

d)

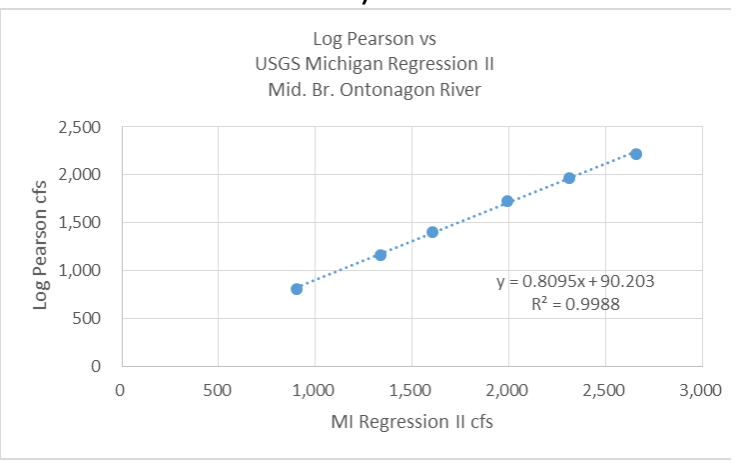

Figure B.1: Linear regression comparing the four peak discharge model outputs with LP3 estimates at the USGS gage on the Middle Branch Ontonagon River (USGS C, 2016). 
a)

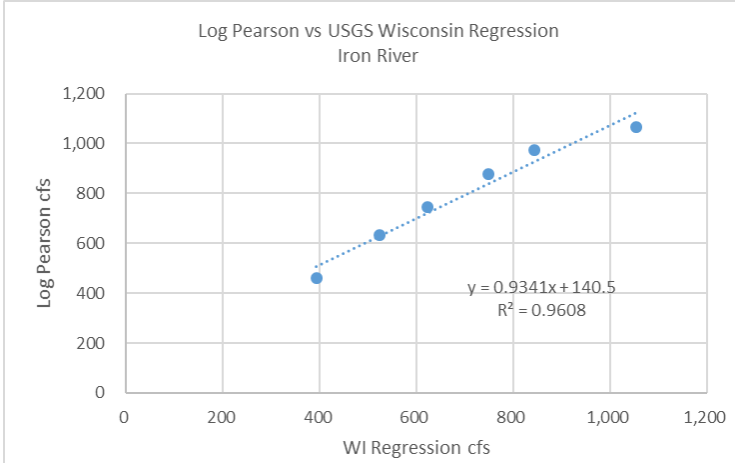

c)

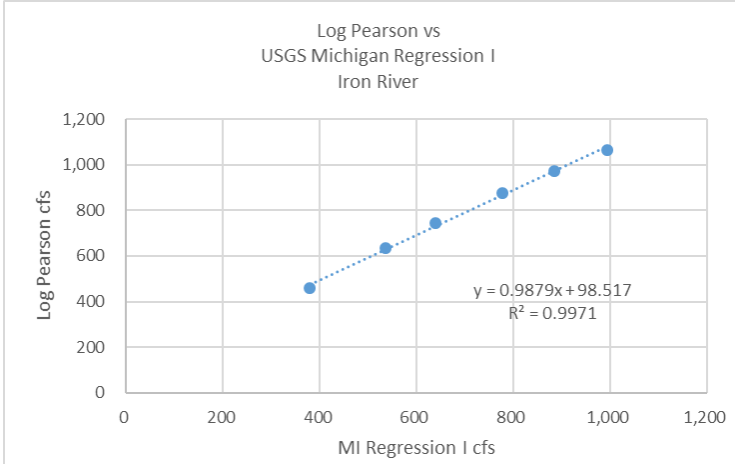

b)

Log Pearson vs MDEQ

Iron River

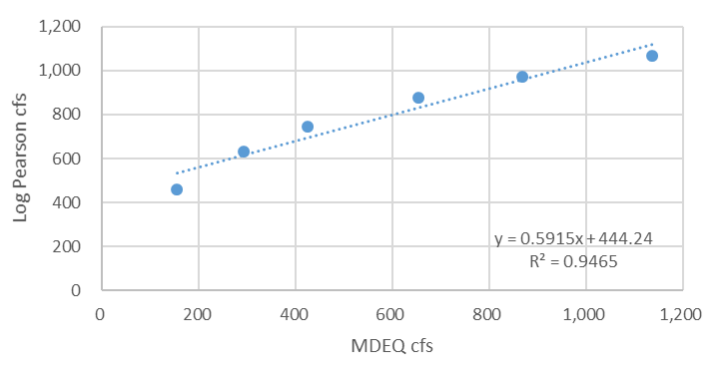

d)

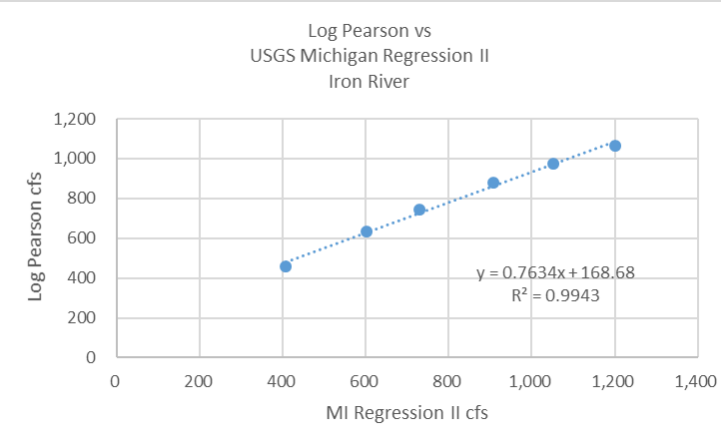

Figure B.2: Linear regression comparing the four peak discharge model outputs with LP3 estimates at the USGS gage on the Iron River (USGS B, 2016). 
a)

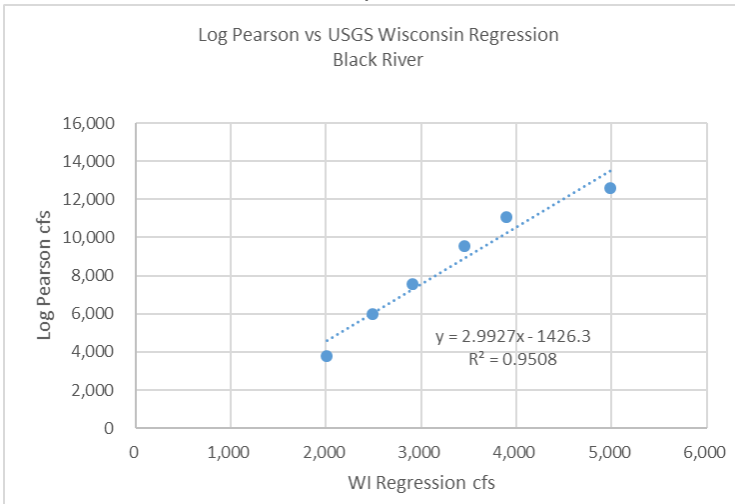

c)

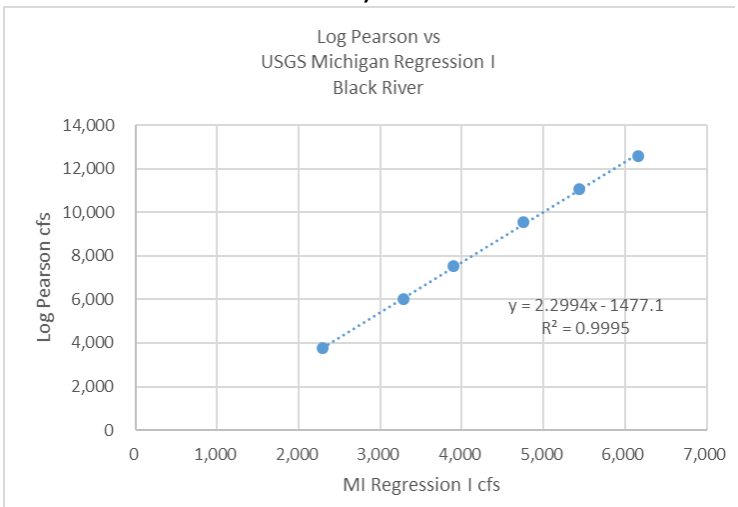

b)

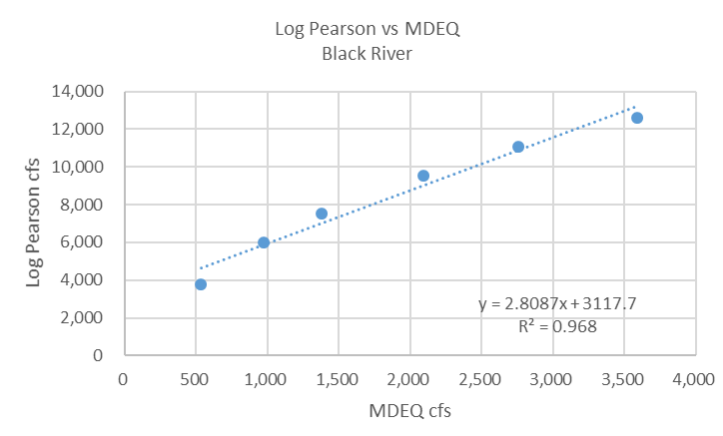

d)

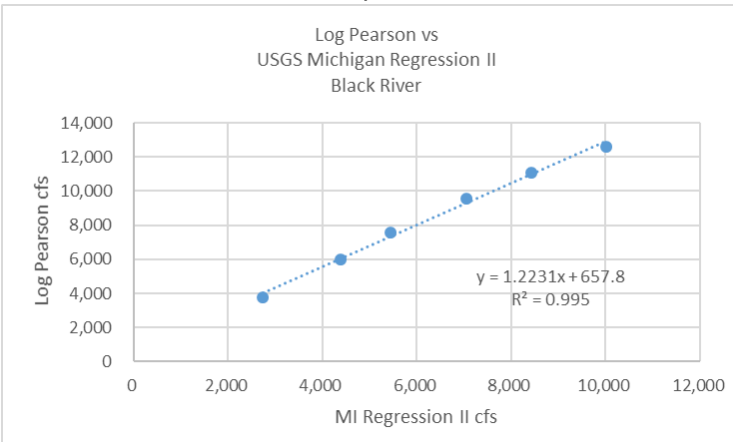

Figure B.2: Linear regression comparing the four peak discharge model outputs with LP3 estimates at the USGS gage on the Black River (USGS A, 2016). 
Appendix C: USGS Michigan Zone 1 regression equations for Q5, Q10, Q25, Q50, and Q100:

$$
\begin{aligned}
& \mathrm{Q} 5=0.9890 * 10^{0.6869} \mathrm{CA}^{0.8931} \mathrm{~S}^{0.2164}(\mathrm{CS}+1)^{-0.1741} \mathrm{SR}^{-0.1148} \mathrm{I}^{1.0458}(\mathrm{OW}+1)^{-0.1524}(\mathrm{M}+1)^{0.1669}(\mathrm{FT}+1)^{0.1017} \\
& (\mathrm{MT}+1)^{0.0884}(\mathrm{C}+1)^{0.0905}(\mathrm{BR}+1)^{0.0963}(\mathrm{CT}+1)^{0.0400} \\
& \mathrm{Q} 10=0.9840 * 10^{0.6688} \mathrm{CA}^{0.8902} \mathrm{~S}^{0.2256}(\mathrm{CS}+1)^{-0.1749} \mathrm{SR}^{-0.1280} \mathrm{I}^{1.1936}(\mathrm{OW}+1)^{-0.1548}(\mathrm{M}+1)^{0.1660}(\mathrm{FT}+1)^{0.1100} \\
& (\mathrm{MT}+1)^{0.1004}(\mathrm{C}+1)^{0.0999}(\mathrm{BR}+1)^{0.0901}(\mathrm{CT}+1)^{0.0443} \\
& \mathrm{Q} 25=0.9790 * 10^{0.6099} \mathrm{CA}^{0.8878} \mathrm{~S}^{0.2372}(\mathrm{CS}+1)^{-0.1744} \mathrm{SR}^{-0.1351} \mathrm{I}^{1.4077}(\mathrm{OW}+1)^{-0.1564}(\mathrm{M}+1)^{0.1666}(\mathrm{FT}+1)^{0.1194} \\
& (\mathrm{MT}+1)^{0.1117}(\mathrm{C}+1)^{0.1091}(\mathrm{BR}+1)^{0.0831}(\mathrm{CT}+1)^{0.0489} \\
& \mathrm{Q} 50=0.9761 * 10^{0.5569} \mathrm{CA}^{0.8860} \mathrm{~S}^{0.2464}(\mathrm{CS}+1)^{-0.1738} \mathrm{SR}^{-0.1414} \mathrm{I}^{1.5657}(\mathrm{OW}+1)^{-0.1569}(\mathrm{M}+1)^{0.1681}(\mathrm{FT}+1)^{0.1254} \\
& (\mathrm{MT}+1)^{0.1184}(\mathrm{C}+1)^{0.1142}(\mathrm{BR}+1)^{0.0784}(\mathrm{CT}+1)^{0.0521} \\
& \mathrm{Q} 100=0.9741 * 10^{0.4936} \mathrm{CA}^{0.8853} \mathrm{~S}^{0.2558}(\mathrm{CS}+1)^{-0.1727} \mathrm{SR}^{-0.1487} \mathrm{I}^{1.7299}(\mathrm{OW}+1)^{-0.1574}(\mathrm{M}+1)^{0.1703}(\mathrm{FT}+1)^{0.1308} \\
& (\mathrm{MT}+1)^{0.1242}(\mathrm{C}+1)^{0.1181}(\mathrm{BR}+1)^{0.0740}(\mathrm{CT}+1)^{0.0539}
\end{aligned}
$$

Where inputs are:

$\mathrm{CA}=$ contributing drainage area $\left(\mathrm{mi}^{2}\right)$

$\mathrm{S}=$ main channel slope $(\mathrm{ft} / \mathrm{mi})$

$\mathrm{CS}=$ river channel length adjacent to swamp, wetlands and open water bodies $(\mathrm{ft})$

$\mathrm{SR}=$ slenderness ratio (hydraulic length ${ }^{2} / \mathrm{CA}$ )

$\mathrm{I}=100 \mathrm{yr}-24 \mathrm{hr}$ precipitation intensity per the 2013 NOAA Atlas (5.81 in)

OW = postglacial alluvium (sand/gravel) in watershed, soil types 3, 7, 8 (\%)

$\mathrm{M}=$ postglacial muck and peat in watershed, soil type $2(\%)$

FT = postglacial fine-textured till in watershed soil type $10(\%)$

MT = postglacial medium-textured till in watershed soil type 10, 11(\%)

$\mathrm{C}=$ lacustrine clay and silt in watershed, soil type 5 (\%)

$\mathrm{BR}=$ bedrock in watershed, soil type $15(\%)$

$\mathrm{CT}=$ postglacial coarse-textured till in watershed, soil type $13(\%)$ 
Appendix D: Coarse inventory data: site, latitude, longitude, potential barrier type, barrier material, barrier dimensions, and fish passability score.

\begin{tabular}{|c|c|c|c|c|c|c|c|c|}
\hline Site ID & Latitude & Longitude & Type & Material & $\begin{array}{l}\text { Length } \\
(\mathrm{ft})\end{array}$ & $\begin{array}{l}\text { Width } \\
(\mathrm{ft})\end{array}$ & $\begin{array}{l}\text { Height } \\
(\mathrm{ft})\end{array}$ & $\begin{array}{c}\text { Passability } \\
\text { Score }\end{array}$ \\
\hline BUSHO3 & 46.2602 & -88.7679 & Bridge & Metal & 12.0 & 40.3 & 3.9 & 0 \\
\hline BUSHO4 & 46.2664 & -88.7740 & Bridge & Metal/Conc. & 16.4 & 43.5 & 8.5 & 0.5 \\
\hline BUSH05 & 46.2590 & -88.8279 & Bridge & Wood & 15.0 & 24.5 & 5.3 & 0.5 \\
\hline BUSH07 & 46.2435 & -88.8392 & Bridge & Metal/Wood & 7.0 & 55.5 & 6.0 & 0.9 \\
\hline BUSH08 & 46.2631 & -88.7716 & Bridge & Wood & 2.8 & 15.5 & 3.0 & 0.9 \\
\hline MITIO2 & 46.3439 & -88.9297 & Bridge & Metal/Conc./Wood & 12.0 & 50.0 & 4.4 & 1 \\
\hline NBPR01 & 46.3156 & -88.7714 & Bridge & Metal/Concrete & 16.7 & 49.5 & 7.2 & 1 \\
\hline NBPRO3 & 46.2988 & -88.8762 & Bridge & Metal/Concrete & 17.9 & 59.0 & 4.9 & 1 \\
\hline NBPR05 & 46.2994 & -88.8527 & Bridge & Metal/Wood & 5.3 & 75.0 & 5.7 & 1 \\
\hline NBPRO6 & 46.2620 & -88.7446 & Bridge & Wood & 5.0 & 100.5 & 5.6 & 1 \\
\hline NBPR07 & 46.2879 & -88.8959 & Bridge & Wood & 4.8 & 43.5 & 2.0 & 1 \\
\hline NBPRO9 & 46.2981 & -88.7464 & Bridge & Metal/Conc./Wood & 10.0 & 130.0 & 6.4 & 1 \\
\hline PNTCR01 & 46.3059 & -88.8824 & Bridge & Wood & 6.0 & 31.5 & 2.1 & 1 \\
\hline PNTCRO3 & 46.2991 & -88.8801 & Bridge & Metal/Wood & 8.0 & 24.5 & 4.3 & 1 \\
\hline POST01 & 46.2421 & -88.8654 & Bridge & Metal/Conc. & 39.5 & 24.0 & 5.7 & 1 \\
\hline THREE01 & 46.2818 & -88.9071 & Bridge & Metal/Concrete & 40.3 & 20.0 & 7.0 & 1 \\
\hline THREE02 & 46.2464 & -88.9303 & Bridge & Metal/Concrete & 32.0 & 12.0 & 4.7 & 1 \\
\hline WINS01 & 46.3333 & -88.7655 & Bridge & Concrete & 20.4 & 24.3 & 3.6 & 1 \\
\hline NBPR08 & 46.2917 & -88.8899 & Bridge & Metal/Wood & 6.0 & 50.0 & 5.5 & 1 \\
\hline BUSHO6 & 46.2296 & -88.8464 & Culvert & Metal & 54.4 & 13.8 & 5.9 & 0 \\
\hline GOLD02 & 46.2847 & -88.6883 & Culvert & Metal & 39.3 & 8.0 & 6.2 & 0 \\
\hline GOLD03 & 46.3156 & -88.6828 & Culvert & Metal & 60.0 & 6.2 & 5.4 & 0 \\
\hline HOLMO2 & 46.3414 & -88.8295 & Culvert & Metal & 44.5 & 7.4 & 5.8 & 0 \\
\hline HOLM03 & 46.3483 & -88.8279 & Culvert & Metal & 19.0 & 5.0 & 3.8 & 0 \\
\hline JESSO & 46.2608 & -88.8407 & Culvert & Metal & 36.0 & 2.9 & 2.1 & 0 \\
\hline MALLARD & 46.2921 & -88.9417 & Culvert & Metal & 48.8 & 7.5 & 4.2 & 0.5 \\
\hline MITI & 46.3430 & -88.9146 & Culvert & Metal & 46.0 & 8.0 & 5.6 & 0.9 \\
\hline MITITRIB01 & 46.3479 & -88.9411 & Culvert & Concrete & 33.0 & 2.5 & 2.5 & 0.9 \\
\hline MITITRIB02 & 46.3405 & -88.9425 & Culvert & Metal & 30.0 & 2.5 & 2.5 & 0.9 \\
\hline NBPRO4 & 46.2931 & -88.9135 & Culvert & Metal & 45.0 & 10.8 & 7.1 & 0.9 \\
\hline NBPR10 & 46.2951 & -88.9193 & Culvert & Metal & 20.0 & 6.0 & 3.5 & 0.9 \\
\hline PAINTCR & 46.3235 & -88.8906 & Culvert & Metal & 23.6 & 5.0 & 5.0 & 0.9 \\
\hline SILK01 & 46.3580 & -88.8836 & Culvert & Metal & 19.5 & 1.3 & 1.3 & 0.9 \\
\hline UNGOLD01 & 46.2891 & -88.6612 & Culvert & Metal & 35.5 & 2.3 & 1.8 & 0.9 \\
\hline UN33 & 46.2426 & -88.9294 & Culvert & Metal & 36.0 & 3.0 & 3.0 & 0 \\
\hline UNWINS & 46.3393 & -88.7555 & Culvert & Metal & 34.5 & 3.0 & 3.0 & 0 \\
\hline BUSH01 & 46.2431 & -88.7393 & Double_Cul & Metal & $45.3^{*}$ & $21.5^{* *}$ & $7.0^{*}$ & 0 \\
\hline NBPR02 & 46.3061 & -88.8092 & Double_Cul & Metal & $24.9 *$ & $3.5^{* *}$ & $7.1^{*}$ & 0.9 \\
\hline WINS & 46.3612 & -88.7606 & Triple_Cul & Metal/Plastic & $32.3^{*}$ & $6.7^{* *}$ & $3.9 *$ & 1 \\
\hline DAM10 & 46.3022 & -88.8186 & Dam & Debris & 21.0 & 20.0 & 4.5 & 0 \\
\hline EPNTDAM01 & 46.3509 & -88.8824 & Dam & Earthen Berm & 25.8 & 5.4 & 2.0 & 0 \\
\hline HOLMDAM01 & 46.3238 & -88.8063 & Dam & Earthen Berm & 49.0 & 60.0 & 5.7 & 0 \\
\hline MALDAM01 & 46.2951 & -88.9193 & Dam & Open Crest & 0.5 & 7.0 & 4.3 & 0 \\
\hline NBPRDAM01 & 46.2992 & -88.8798 & Dam & Open Crest & 7.5 & 29.0 & 1.8 & 0 \\
\hline NBPRDAM02 & 46.2998 & -88.8640 & Dam & Open Crest & 10.5 & 8.0 & 1.0 & 0 \\
\hline PAINTDAM01 & 46.3338 & -88.8854 & Dam & Earthen Berm & 174.0 & 16.0 & 2.6 & 0 \\
\hline WINSDAM01 & 46.3337 & -88.7653 & Dam & Earthen Berm & 32.0 & 20.8 & 3.5 & 0 \\
\hline HOLM01 & 46.3375 & -88.8139 & Ford & NA & 8.0 & 47.6 & NA & 1 \\
\hline UNKNBPR01 & 46.2983 & -88.8228 & Ford & NA & 8.5 & 7.9 & NA & 1 \\
\hline
\end{tabular}


Appendix E: Surveyed culvert sites and the respective failure ratio, watershed attributes, and coefficients derived by comparing failure ratio with attributes.

\begin{tabular}{|c|c|c|c|c|c|c|c|c|c|}
\hline Site & $\begin{array}{l}\text { failure } \\
\text { ratio }\end{array}$ & $\begin{array}{l}\text { watershed } \\
\text { slope }\end{array}$ & $\begin{array}{c}\text { area weighted } \\
\text { permeability }\end{array}$ & $\begin{array}{l}\text { main channel } \\
\text { length }\end{array}$ & $\begin{array}{l}\text { total channel } \\
\text { length }\end{array}$ & $\begin{array}{l}\text { hydraulic } \\
\text { length }\end{array}$ & $\begin{array}{l}\text { watershed } \\
\text { area }\end{array}$ & $\begin{array}{l}\text { storage } \\
\text { area }\end{array}$ & $\begin{array}{l}\text { main } \\
\text { channel } \\
\text { slope }\end{array}$ \\
\hline & & $\%$ & in/hr & $\mathrm{ft}$ & $\mathrm{ft}$ & $\mathrm{ft}^{2}$ & $\mathrm{ft}^{2}$ & $\mathrm{ft}^{2}$ & $\%$ \\
\hline BUSH01 & 3.1 & 2.8 & 6.3 & 67901 & 135643 & 73341 & 672705792 & 154167552 & 0.24 \\
\hline BUSHOG & 3.9 & 2.6 & 6.4 & 6088 & 6088 & 8044 & 44719741 & 6651786 & 0.70 \\
\hline JESSO & 0.3 & 3.1 & 2.8 & 1997 & 1997 & 8553 & 24086938 & 4583209 & 0.97 \\
\hline MALLARD & 1.2 & 2.8 & 6.1 & 3392 & 3906 & 9513 & 78065096 & 32991299 & 0.39 \\
\hline MITI & 0.9 & 3.8 & 5.5 & 12938 & 16971 & 19862 & 169821274 & 54223488 & 0.50 \\
\hline NBPRO2 & 1.8 & 3.2 & 8.2 & 62864 & 146786 & 67746 & 1284112558 & 372915418 & 0.12 \\
\hline NBPR04 & 2.2 & 4.1 & 6.6 & 14492 & 14492 & 20391 & 204412792 & 75388769 & 0.08 \\
\hline PAINTCR & 0.1 & 3.6 & 6.6 & 30994 & 47150 & 37927 & 392527872 & 129913344 & 0.20 \\
\hline UN33 & 0.9 & 2.4 & 13.0 & 362 & 362 & 7920 & 14809006 & 2135485 & 0.35 \\
\hline UNWINS & 0.9 & 1.5 & 9.5 & 2273 & 2273 & 6500 & 14443799 & 5623073 & 0.39 \\
\hline WINS & 1.1 & 1.8 & 8.7 & 14642 & 16483 & 18526 & 71273917 & 34583155 & 0.25 \\
\hline$R$ & & -0.007 & -0.048 & 0.331 & 0.325 & 0.287 & 0.220 & 0.149 & -0.075 \\
\hline$R^{2}$ & & 0.00005 & 0.002 & 0.110 & 0.106 & 0.082 & 0.048 & 0.022 & 0.006 \\
\hline$P$ & & 0.135 & 0.079 & 0.010 & 0.236 & 0.029 & 0.440 & 0.008 & 0.158 \\
\hline
\end{tabular}


Appendix F: Surveyed culvert sites and the respective failure ratio, culvert dimensions, and $R^{2}$ values derived by comparing failure ratio with dimensions.

\begin{tabular}{|c|c|c|c|c|c|c|c|}
\hline Site & $\begin{array}{l}\text { failure } \\
\text { ratio }\end{array}$ & $\begin{array}{c}\text { culvert } \\
\text { slope } \\
\%\end{array}$ & $\begin{array}{c}\text { culvert } \\
\text { width } \\
\mathrm{ft}\end{array}$ & $\begin{array}{c}\text { culvert } \\
\text { height } \\
\mathrm{ft}\end{array}$ & $\begin{array}{c}\text { culvert } \\
\text { length } \\
\mathrm{ft}\end{array}$ & $\begin{array}{c}\text { culvert } \\
\text { inlet } \\
\text { area } \\
\mathrm{ft}^{2}\end{array}$ & $\begin{array}{c}\text { culvert } \\
\text { volume } \\
\mathrm{ft}^{3}\end{array}$ \\
\hline BUSH01 & 3.109 & 0.6 & 21.5 & 7.0 & 45.3 & 95.0 & 4300.1 \\
\hline BUSH06 & 3.860 & 0.8 & 13.8 & 5.9 & 54.4 & 56.5 & 3076.3 \\
\hline JESSO & 0.299 & 2.1 & 2.9 & 2.1 & 36.0 & 4.8 & 172.2 \\
\hline MALLARD & 1.163 & 2.7 & 7.5 & 4.2 & 48.8 & 27.7 & 1350.9 \\
\hline MITI & 0.907 & 0.4 & 8.0 & 5.6 & 46.0 & 35.2 & 1618.7 \\
\hline NBPRO2 & 1.799 & 3.0 & 23.5 & 7.1 & 24.9 & 158.4 & 3944.2 \\
\hline NBPRO4 & 2.230 & 1.2 & 10.8 & 7.1 & 45.0 & 60.0 & 2697.8 \\
\hline PAINTCR & 0.076 & 1.7 & 5.0 & 5.0 & 23.6 & 19.6 & 463.7 \\
\hline UN33 & 0.885 & 0.4 & 3.0 & 3.0 & 36.0 & 7.1 & 254.5 \\
\hline UNWINS & 0.902 & 0.2 & 3.0 & 3.0 & 34.5 & 7.1 & 243.9 \\
\hline WINS & 1.104 & 2.3 & 6.7 & 3.9 & 32.3 & 19.4 & 624.0 \\
\hline $\mathrm{R}$ & & -0.201 & 0.706 & 0.657 & 0.624 & 0.558 & 0.817 \\
\hline$R^{2}$ & & 0.040 & 0.498 & 0.432 & 0.389 & 0.311 & 0.667 \\
\hline$P$ & & 0.876 & 0.905 & 0.557 & 0.971 & 0.518 & 0.448 \\
\hline
\end{tabular}


Appendix G: Surveyed culvert site and the respective failure ratio, upstream bankfull conditions, and $\mathrm{R}^{2}$ values derived by comparing failure ratio with conditions.

\begin{tabular}{lcccc}
\hline Site & $\begin{array}{c}\text { failure } \\
\text { ratio }\end{array}$ & $\begin{array}{c}\text { bankfull } \\
\text { width } \\
\mathrm{ft}\end{array}$ & $\begin{array}{c}\text { average bankfull } \\
\text { depth } \\
\mathrm{ft}\end{array}$ & $\begin{array}{c}\text { bankfull } \\
\text { area } \\
\mathrm{ft}^{2}\end{array}$ \\
\hline BUSH01 & 3.109 & 51.0 & 1.7 & 88.3 \\
BUSH06 & 3.860 & 7.8 & 1.0 & 12.8 \\
JESSO & 0.299 & 10.0 & 0.6 & 4.7 \\
MALLARD & 1.163 & 33.0 & 0.8 & 12.7 \\
MITI & 0.907 & 23.5 & 1.7 & 44.0 \\
NBPR02 & 1.799 & 36.0 & 2.8 & 108.8 \\
NBPR04 & 2.230 & 18.0 & 0.4 & 7.6 \\
PAINTCR & 0.076 & 89.2 & 1.6 & 135.5 \\
UN33 & 0.885 & 6.0 & 0.4 & 4.2 \\
UNWINS & 0.902 & 12.8 & 1.5 & 41.6 \\
WINS & 1.104 & 4.5 & 0.4 & 7.1 \\
\hline R & & -0.163 & 0.095 & -0.076 \\
R & & 0.0266 & 0.009 & 0.0058 \\
P & & 0.994 & 0.616 & 0.780 \\
\hline
\end{tabular}


Appendix $\mathrm{H}$ : Metric, metric description, units, $\mathrm{R}$ values, and $\mathrm{R}^{2}$ values of all metrics used in correlations.

\begin{tabular}{|c|c|c|c|c|}
\hline Metric & Metric description & Units in equation & $\mathrm{R}$ & $\mathrm{R}^{2}$ \\
\hline b & (culvert width $\mathrm{x}$ hydraulic length)/watershed area & $\mathrm{ft}^{2} / \mathrm{ft}^{2}$ & 0.800 & 0.640 \\
\hline c & culvert height/culvert width & $\mathrm{ft} / \mathrm{ft}$ & -0.708 & 0.501 \\
\hline e & (culvert length $x$ total channel length)/watershed area & $\mathrm{ft}^{2} / \mathrm{ft}^{2}$ & 0.683 & 0.466 \\
\hline$f$ & culvert width/hydraulic length & $\mathrm{ft} / \mathrm{ft}$ & 0.670 & 0.449 \\
\hline i & inlet area/storage area & $\mathrm{ft}^{2} / \mathrm{ft}^{2}$ & 0.597 & 0.356 \\
\hline j & culvert length/culvert width & $\mathrm{ft} / \mathrm{ft}$ & -0.568 & 0.323 \\
\hline $\mathrm{k}$ & (culvert width $\mathrm{x}$ culvert length)/bankfull area & $\mathrm{ft}^{2} / \mathrm{ft}^{2}$ & 0.545 & 0.297 \\
\hline I & inlet area/watershed area & $\mathrm{ft}^{2} / \mathrm{ft}^{2}$ & 0.542 & 0.294 \\
\hline $\mathrm{m}$ & inlet area/bankfull area & $\mathrm{ft}^{2} / \mathrm{ft}^{2}$ & 0.523 & 0.274 \\
\hline$q$ & bankfull area/inlet area & $\mathrm{ft}^{2} / \mathrm{ft}^{2}$ & -0.483 & 0.234 \\
\hline r & (culvert width $\mathrm{x}$ culvert length)/watershed area & $\mathrm{ft}^{2} / \mathrm{ft}^{2}$ & 0.468 & 0.219 \\
\hline $\mathrm{s}$ & bankfull area/(culvert width x culvert length) & $\mathrm{ft}^{2} / \mathrm{ft}^{2}$ & -0.450 & 0.202 \\
\hline $\mathrm{t}$ & storage area/inlet area & $\mathrm{ft}^{2} / \mathrm{ft}^{2}$ & -0.413 & 0.171 \\
\hline u & bankfulll width/culvert height & $\mathrm{ft} / \mathrm{ft}$ & -0.388 & 0.151 \\
\hline $\mathrm{v}$ & main channel slenderness ratio & $\mathrm{mi}^{2} / \mathrm{mi}^{2}$ & 0.386 & 0.149 \\
\hline w & culvert width/culvert length & $\mathrm{ft} / \mathrm{ft}$ & 0.383 & 0.147 \\
\hline$x$ & watershed area/inlet area & $\mathrm{ft}^{2} / \mathrm{ft}^{2}$ & -0.376 & 0.141 \\
\hline y & culvert height/hydraulic length & $\mathrm{ft} / \mathrm{ft}$ & 0.375 & 0.141 \\
\hline z & culvert height/bankfull width & $\mathrm{ft} / \mathrm{ft}$ & 0.353 & 0.125 \\
\hline
\end{tabular}


Appendix $\mathrm{H}$ continued: Metric, metric description, units, $\mathrm{R}$ values, and $\mathrm{R}^{2}$ values of all metrics used in correlations.

\begin{tabular}{|c|c|c|c|c|}
\hline Metric & Metric description & Units in equation & $\mathrm{R}$ & $\mathrm{R}^{2}$ \\
\hline aa & (total channel length $\mathrm{x}$ watershed slope)/(culvert length $\mathrm{x}$ culvert slope) & $\left(\mathrm{ft}^{2} \mathrm{x} \%\right) /\left(\mathrm{ft}^{2} \mathrm{x} \%\right)$ & 0.351 & 0.123 \\
\hline$a b$ & (culvert inlet area x culvert slope)/(watershed area $\mathrm{x}$ watershed slope) & $\left(\mathrm{ft}^{2} \mathrm{x} \%\right) /\left(\mathrm{ft}^{2} \mathrm{x} \%\right)$ & 0.347 & 0.120 \\
\hline ac & hydraulic length/watershed area & $\mathrm{mi} / \mathrm{mi}^{2}$ & -0.344 & 0.118 \\
\hline $\mathrm{ad}$ & (culvert length $\mathrm{x}$ culvert slope)/(total channel length $\mathrm{x}$ watershed slope) & $(\mathrm{ft} \times \%) /(\mathrm{ft} \times \%)$ & -0.324 & 0.105 \\
\hline ae & culvert length/culvert height & $\mathrm{ft} / \mathrm{ft}$ & -0.313 & 0.098 \\
\hline af & (main channel length $\mathrm{x}$ main channel slope)/(culvert length $\mathrm{x}$ culvert slope) & (ft x \%) / (ft x \%) & 0.304 & 0.092 \\
\hline ag & bankfull width/cuvlert length & $\mathrm{ft} / \mathrm{ft}$ & -0.290 & 0.084 \\
\hline ah & total channel length/watershed area & $\mathrm{mi} / \mathrm{mi}^{2}$ & 0.280 & 0.078 \\
\hline ai & watershed area/(culvert width $\mathrm{x}$ culvert length) & $\mathrm{ft}^{2} / \mathrm{ft}^{2}$ & -0.270 & 0.073 \\
\hline aj & hydraulic length/total channel length & $\mathrm{mi} / \mathrm{mi}$ & -0.244 & 0.060 \\
\hline ak & (watershed area $\mathrm{x}$ watershed slope)/(culvert inlet area $\mathrm{x}$ culvert slope) & $\left(\mathrm{ft}^{2} \mathrm{x} \%\right) /\left(\mathrm{ft}^{2} \mathrm{x} \%\right)$ & -0.231 & 0.054 \\
\hline al & main channel length/culvert height & $\mathrm{ft} / \mathrm{ft}$ & 0.231 & 0.053 \\
\hline am & (culvert length $\mathrm{x}$ culvert slope)/(main channel length $\mathrm{x}$ main channel slope) & $(\mathrm{ft} \times \%) /(\mathrm{ft} \times \%)$ & -0.227 & 0.052 \\
\hline an & culvert length/main channel length & $\mathrm{ft} / \mathrm{ft}$ & -0.220 & 0.048 \\
\hline ao & (hydraulic length $\mathrm{x}$ watershed slope)/(culvert length $\mathrm{x}$ culvert slope) & (ft $x \%) /(f t x \%)$ & 0.216 & 0.047 \\
\hline ap & cuvlert length/bankfull width & $\mathrm{ft} / \mathrm{ft}$ & 0.200 & 0.040 \\
\hline aq & 100 yr 24 hr precipitation intensity/area weighted permeability* & (in/hr) / (in/hr) & -0.195 & 0.038 \\
\hline $\operatorname{ar}$ & main channel length/culvert width & $\mathrm{ft} / \mathrm{ft}$ & -0.192 & 0.037 \\
\hline as & culvert height/main channel length & $\mathrm{ft} / \mathrm{ft}$ & -0.185 & 0.034 \\
\hline at & (culvert length $\mathrm{x}$ hydraulic length)/watershed area & $\mathrm{ft}^{2} / \mathrm{ft}^{2}$ & -0.185 & 0.034 \\
\hline au & culvert slope/watershed slope & $\% / \%$ & -0.183 & 0.034 \\
\hline av & main channel length/watershed area & $\mathrm{mi} / \mathrm{mi}^{2}$ & 0.165 & 0.027 \\
\hline aw & main channel length/culvert length & $\mathrm{ft} / \mathrm{ft}$ & 0.149 & 0.022 \\
\hline ax & culvert length/hydraulic length & $\mathrm{ft} / \mathrm{ft}$ & 0.136 & 0.019 \\
\hline ay & culvert height/culvert length & $\mathrm{ft} / \mathrm{ft}$ & 0.132 & 0.018 \\
\hline az & main channel length/total channel length & $\mathrm{mi} / \mathrm{mi}$ & -0.115 & 0.013 \\
\hline
\end{tabular}

* uses the NOAA, 2013 precipitation intensity $\left(5.81 \mathrm{inhr}^{-1}\right)$ 
Appendix $\mathrm{H}$ continued: Metric, metric description, units, $\mathrm{R}$ values, and $\mathrm{R}^{2}$ values of all metrics used in correlations.

\begin{tabular}{|c|c|c|c|c|}
\hline Metric & Metric description & Units in equation & $\mathrm{R}$ & $\mathrm{R}^{2}$ \\
\hline ba & hydraulic lengthslenderness ratio & $\mathrm{mi}^{2} / \mathrm{mi}^{2}$ & 0.113 & 0.013 \\
\hline $\mathrm{bb}$ & culvert width/main channel length & $\mathrm{ft} / \mathrm{ft}$ & -0.088 & 0.008 \\
\hline bc & main channel slope/culvert slope & $\% / \%$ & -0.088 & 0.008 \\
\hline bd & hydraulic length/culvert length & $\mathrm{ft} / \mathrm{ft}$ & 0.087 & 0.008 \\
\hline be & (culvert length $\mathrm{x}$ culvert slope)/(hydraulic length $\mathrm{x}$ watershed slope) & $(\mathrm{ft} \times \%) /(\mathrm{ft} \times \%)$ & -0.074 & 0.005 \\
\hline bf & hydraulic length/culvert height & $\mathrm{ft} / \mathrm{ft}$ & 0.070 & 0.005 \\
\hline bg & area weighted permeability/100 yr 24 hr precipitation intensity* & (in/hr) / (in/hr) & -0.048 & 0.002 \\
\hline bh & watershed slope/culvert slope & $\% / \%$ & -0.048 & 0.002 \\
\hline bi & culvert slope/main channel slope & $\% / \%$ & 0.046 & 0.002 \\
\hline
\end{tabular}

* uses the NOAA, 2013 precipitation intensity $\left(5.81 \mathrm{inhr}^{-1}\right)$ 